\title{
Prediction Experiment of Extremely Intense Rainstorm by a Very-Fine Mesh Primitive Equation Model
}

\author{
By K. Ninomiya \\ Sendai District Meteorological Observatory, Sendai 983 \\ H. Koga, Y. Yamagishi and Y. Tatsumi \\ Electronic Computation Center, Japan Meteorological Agency, Tokyo 100 \\ (Manuscript received 17 November 1983, in revised form 20 February 1984)
}

\begin{abstract}
Forecast experiment is made using a 13-level $42 \mathrm{~km}$-mesh primitive equation model for the extremely intense rainstorm event which occurred over western Japan on 23 July 1982. The rainstorm was associated with a meso- $\alpha$-scale depression and a low-level convergence line developed in a subtropical frontal zone, but not with an intense synoptic-scale trough. The large amount of precipitation (maximum $\sim 500 \mathrm{~mm}$ ) was concentrated in a narrow area ( $\sim 100 \mathrm{~km}$ square) and for a short time span (6 12 hours).

Several aspects of the rainstorm including the concentration of the rainfall, development of the meso- $\alpha$-scale depression and the convergence line are simulated in the model. However the predicted precipitation rate $(\sim 70 \mathrm{~mm} / 6$ hour $)$ is much smaller than that observed.

Dynamical and thermodynamical processes involved in the occurrence of the rainstorm, such as the moisture convergence, changes in the vertical stability, diabatic heating, changes in vorticity and divergence fields are described on the basis of the experiment.

The effect of the increase of the horizontal resolution in the model on the prediction of rainfall rate and the meso- $\alpha$-scale circulation is also examined by comparing the model predictions with the different horizontal grid sizes $(42 \mathrm{~km}, 63 \mathrm{~km}$ and $127 \mathrm{~km})$. The result indicates that both the precipitation rate and the total amount of precipitation are increased with the finer grid sizes. This is attributed to the increase in both magnitude and the degree of concentration of the moisture convergence in the lower layers.

The result of a forecast experiment on another intense rainfall event over the western part of Japan in 22 23 July 1983 is also discussed.
\end{abstract}

\section{Introduction}

The numerical prediction of precipitation caused by middle latitude large-scale disturbance have been successfully achieved by the primitive equation model. Many authors (e.g., Hovermale, 1975 ; Miyakoda and Rosati, 1977 ; Anthes and Keyser, 1979) stressed in their papers on forecast experiments that the improvement in accuracy of rainfall prediction by primitive equation models is achieved through increased grid resolution of the model. Anthes et al. (1982) was able to predict the change of environment of severe local storms by an fine-mesh primitive equation model. Ross and Orlanski (1982) also simulate the evolution of a cold front and associated intense rainfall by an anelastic equation model.

Very intensive, concentrated convective rainfall events are frequently associated with mesoscale disturbances in the summer season in some southern parts of the middle latitude and subtropical areas where the baroclinicity of the atmosphere is not necessarily strong. For example, intensive convective rains occur frequently over southwestern Japan in the rain season (Baiu season). Many observational studies (Akiyama, 1973, 1975, 1978 and 1979; 
Matsumoto et al., 1971; Ninomiya and Akiyama, 1972 and 1974; Ninomiya and Yamazaki, 1979 ; Ninomiya et al., 1981 ; Yoshizumi, 1977) revealed the mesoscale features of the convective rainfalls in the Baiu season. The numerical prediction of such intense rainfalls is still a problem remaining to be improved. The operational 11 -level $127 \mathrm{~km}$-mesh primitive equation model of J.M.A. (Tatsumi, 1982) does not always predict accurately the development of the meso- $\alpha$-scale depression and associated precipitation in the Baiu season.

Ninomiya and Tatsumi $(1980,1981)$ made forecast experiments of intensive rainfulls in the Baiu season using a 6 -level $77 \mathrm{~km}$-mesh primitive equation model. They were able to simulate the disturbance and associated rainfalls accurately to some extent. Recently Yamagishi and Koga have developed 11-level $63 \mathrm{~km}$-mesh and 13-level $42 \mathrm{~km}$-mesh primitive equation model to predict the fine structure of the large-scale disturbance, mesoscale disturbance and orographically induced circulation system over the Japan Islands (Staff members of ECC, JMA, 1983).

On 23 July 1982, extremely intensive rainfalls occurred over southwestern part of Japan (Kyushu). The precipitation of $\sim 400 \mathrm{~mm} /$ day was recorded at Nagasaki city. The forecast experiment or simulation on such extremely intensive rainfalls has not been made yet. In the present study, a forecast experiment is made using a 13-level $42 \mathrm{~km}$-mesh primitive equation model for this rainstorm event. We also describe the dynamical and thermodynamical processes involved in the occurrence of the rainstorm on the basis of the experiment.

\section{Observed feature of the intensive rainfalls}

We will briefly describe observed feature of the intensive rainfalls and the related disturbances.

The rainfalls were concentrated within a narrow area of $\sim(100 \mathrm{~km})^{2}$ in the northwestern part of Kyushu. The horizontal dimension of the related meso- $\alpha$-scale depression or circulation system is $300 \sim 500 \mathrm{~km}$. The smallness of this phenomenon will be realized by comparing the size of the Japan Islands with that of the United States (Fig. 1). The latitude of Kyushu is approximately equal to that of the Gulf States. The dimension of Kyushu is about $1 / 5$ of the State of Louisiana. The scale of the present heavy rainfalls is much smaller than those simulated by Anthes et al. (1982) or Ross and Orlanski (1982).

Precipitation distributions for $06 \sim 12$ GMT 23 and 18 GMT 23 00 GMT 24 July 1982 are shown in Fig. 2. The precipitation was most

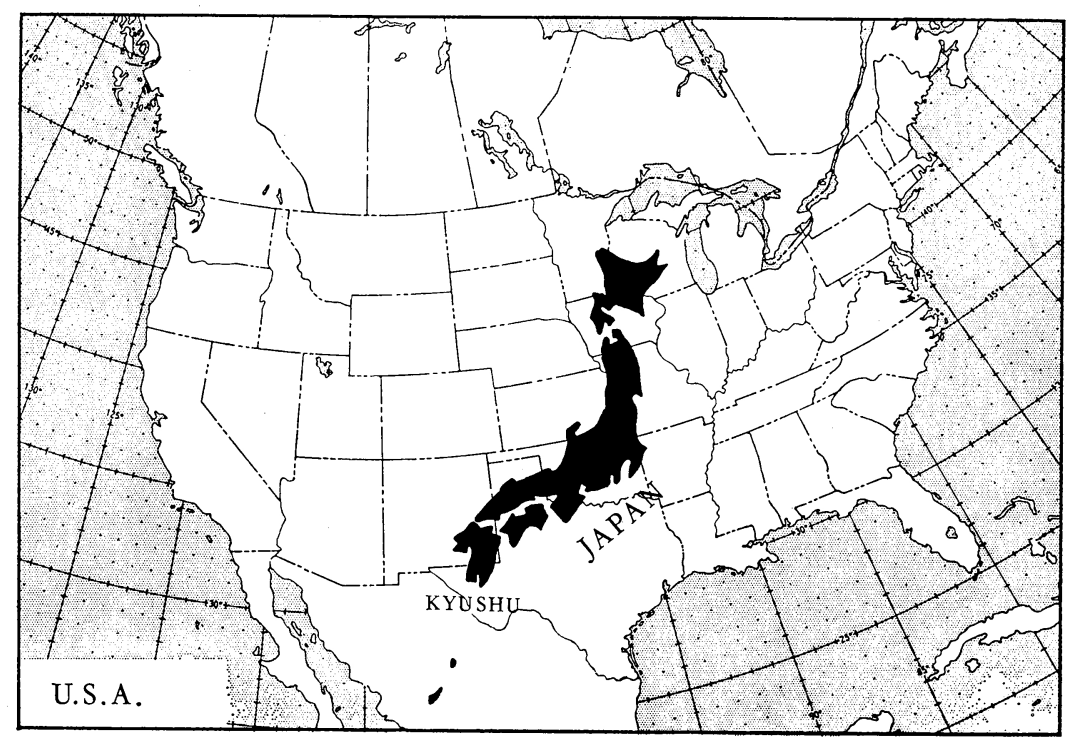

Fig. 1 Comparison of the size of the Japan Islands to that of the U.S.A. 
I2 GMT 23 JUL 1982

OBS, RAINFALL

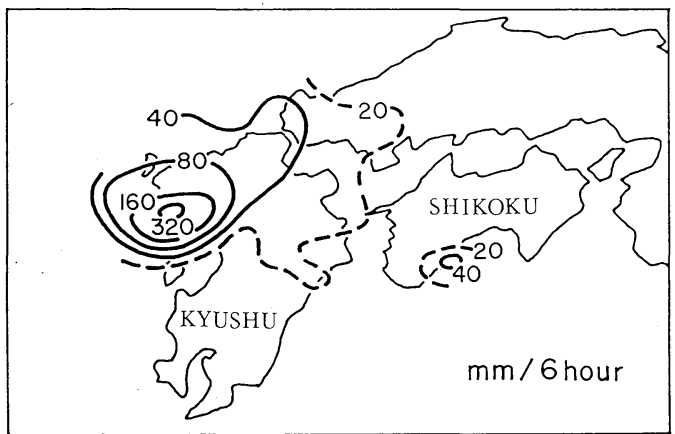

OOGMT 24 JUL 1982

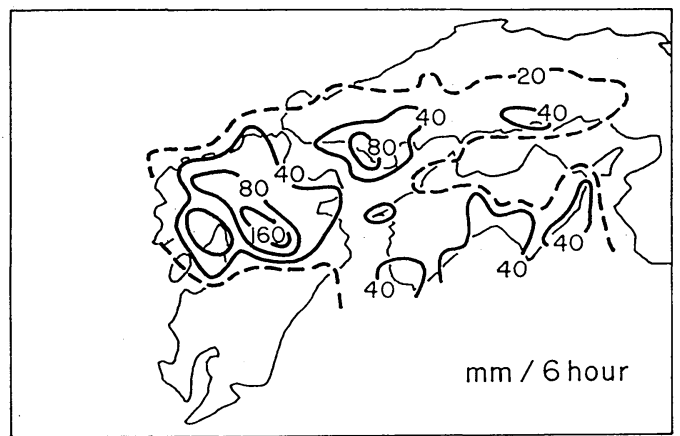

Fig. 2 Precipitation maps for 06 12 GMT 23 and 18 GMT 23 00 GMT 24 July 1982 (unit: $\mathrm{mm} / 6$ hour).

intense during $06 \sim 18$ GMT 23 , and the precipitation observed at Nagasaki City amounted to $\sim 400 \mathrm{~mm} /$ day. After this peak period, precipitation weakened gradually and the intense precipitation area moved eastward.

Maps of $T_{B B}$ (cloud top IR black body temperature measured by Geostationary Meteorological Satellite) at 12 GMT 23 and 00 GMT 24 July 1982 are presented in Fig. 3. At the peak period of precipitation (12 GMT 23), an area of very low $T_{B B}\left(\sim-70^{\circ} \mathrm{C}\right)$ is seen over Kyushu. At 00 GMT 24, the low $T_{B B}$ area is found over western Japan $\left(\sim 134^{\circ} \mathrm{E}\right)$. It is also seen that low $T_{B B}$ zone (convective cloud zone) of $\sim 100 \mathrm{~km}$ width extends along $\sim 32^{\circ} \mathrm{N}$ latitude from southern part of China toward western part of Japan, and a few cloud cluster alignied in this low $T_{B B}$ zone.

Fig. 4 shows $850 \mathrm{mb}$ height and wind field at 00 GMT 23, 12 GMT 23 and 00 GMT 24 Juily 1982. The broken lines in the maps are isolines of $850 \mathrm{mb}$ height change $(\partial z / \partial t)$ in the preceding 12 hours. There was a stationary
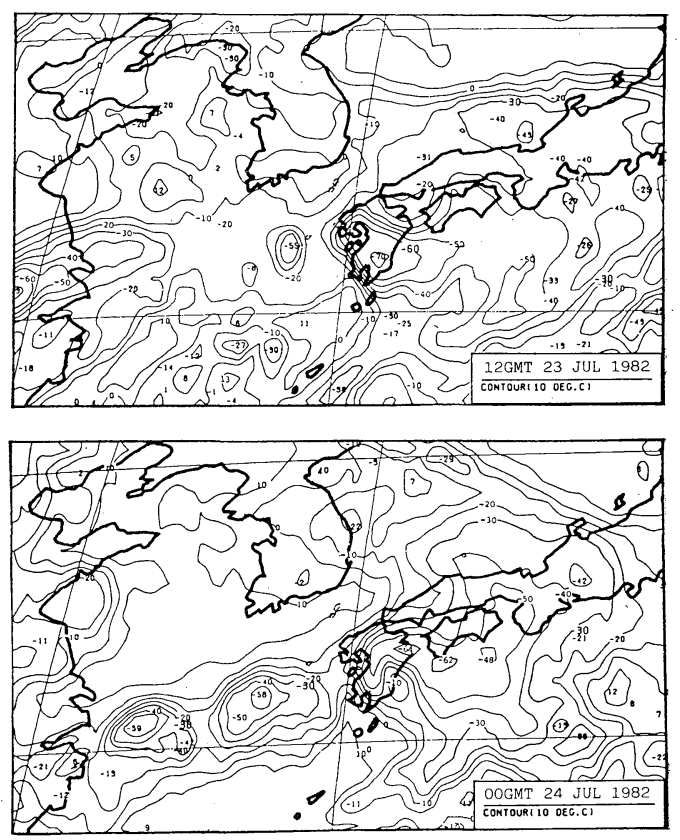

Fig. 3 Maps of $T_{B B}$ (cloud top IR black body temperature measured by Geostationary Meteorological Satellite) at 12 GMT 23 and 00 GMT 24 July 1982. The isolines are given at $10^{\circ} \mathrm{C}$ interval. These maps are reproduced from "GMS observations of heavy rainfall of July 1982", Extra Issue of Meteorological Satellite Center Technical Note. 1982.

synoptic-scale depression (see $1410 \mathrm{~m}$ contour line) to the south of the Korea Peninsula. Although the synoptic-scale depression was stationary, pattern of $\partial z / \partial t$ clearly indicates a weak meso- $\alpha$-scale depression moving slowly eastward.

At $850 \mathrm{mb}$, a zone of strong wind (20 30 knot) extended from the southern part of China $\left(\sim 30^{\circ} \mathrm{N}\right)$ to the meso- $\alpha$-scale depression. The zone of $700 \mathrm{mb}$ moist air (see Fig. 5) and the convective cloud zone (Fig. 3) were located along this zone of $850 \mathrm{mb}$ strong wind. A strong cyclonic circulation was found around the meso- $\alpha$-scale depression, i. e., strong southwesterly and northeasterly winds are found in the southeast and northeast sides the depression respectively.

The deepening of the meso- $\alpha$-scale depression $(\partial z / \partial t)$ was maximized $(\sim 40 \mathrm{~m} / 12$ hour $)$ around 12 GMT 23. Concurrent with the deepening of the depression, low-level southwesterly and easterly winds were enhanced 
OOGMT 23 JUL $1982850 \mathrm{mb}$

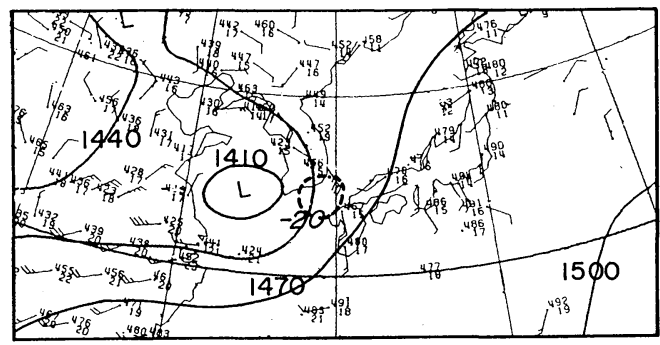

12 GMT 23 JUL $1982850 \mathrm{mb}$

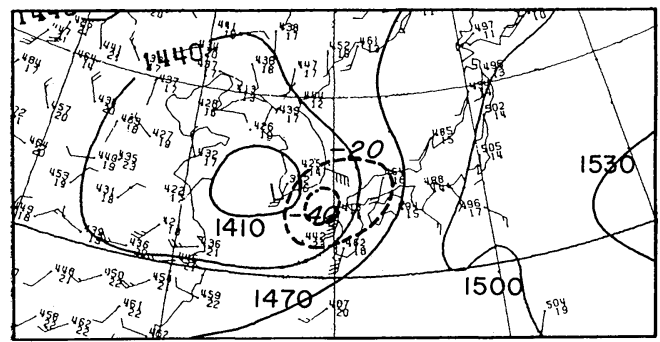

OOGMT 24 JUL $1982850 \mathrm{mb}$

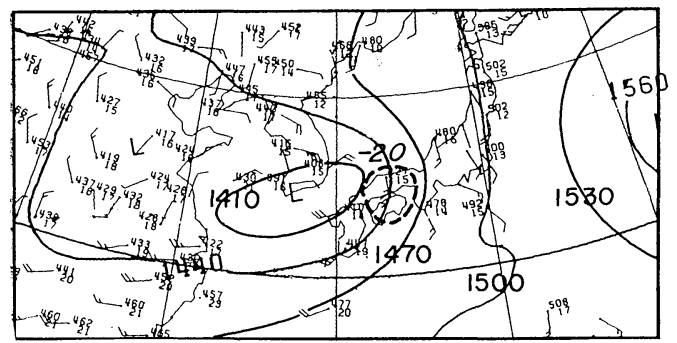

Fig. 4 The $850 \mathrm{mb}$ height contours (solid lines) and $850 \mathrm{mb}$ winds at 00 GMT 23, 12 GMT 23 and 00 GMT 24 July 1982. The broken lines are isolines of $850 \mathrm{mb}$ height change $(\partial Z / \partial t$ : $\mathrm{m} / 12$ hour) in the preceding 12 -hour. A full wind berb indicates $10 \mathrm{knot}(5 \mathrm{~m} / \mathrm{sec})$.

significantly to the south and the north of the depression respectively, and a shear line was formed around the north side of Kyushu between the southwesterly flow and easterly flow. The rapid fall of the height and the formation of the shear line were observed only in the lower troposphere $(1000 \sim 700 \mathrm{mb})$ but not in the upper troposphere. This indicates that this meso- $\alpha$-scale depression and circulation system were confined within the lower layers.

Fig. 5 shows wind, temperature and mixing ratio field at 850 and $700 \mathrm{mb}$ level at 12 GMT 23 July 1982 . The main polar frontal zone was located in $\sim 50^{\circ} \mathrm{N}$, and the secondary baroclinic zone was seen along $\sim 33^{\circ} \mathrm{N}$ over
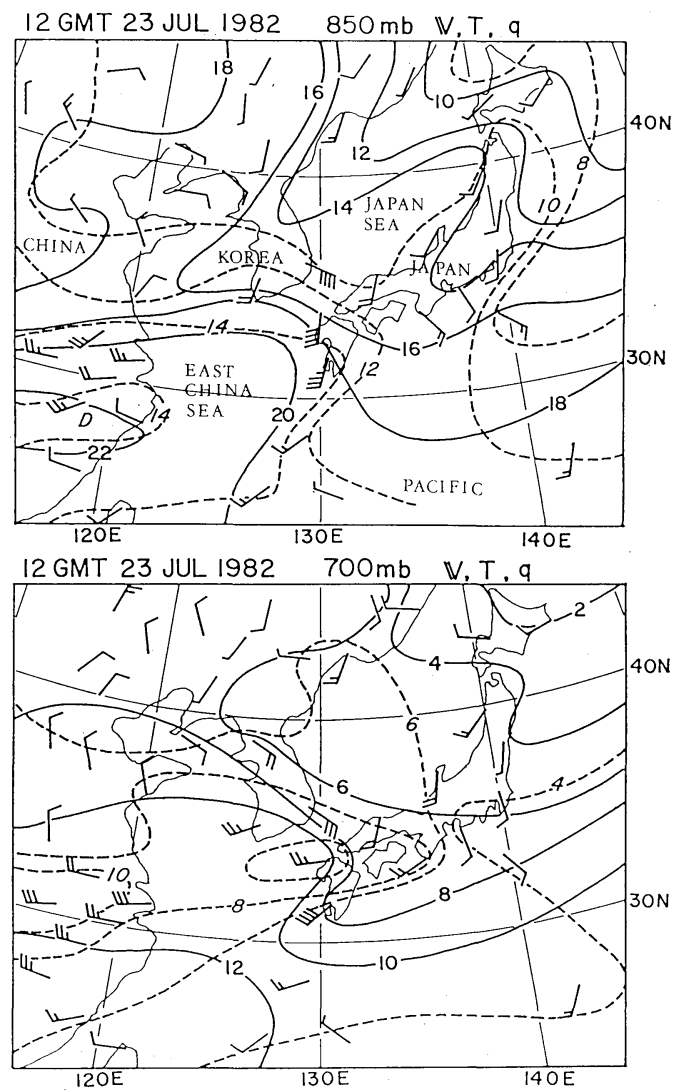

Fig. 5 Winds, temperature (solid lines) and mixing-ratio (broken line) at $850 \mathrm{mb}$ and $700 \mathrm{mb}$ at 12 GMT 23 July 1982 . A full wind berb indicates $10 \mathrm{knot}(5 \mathrm{~m} / \mathrm{sec})$.

the East China Sea. The aforementioned convective cloud zone (zone of low $T_{B B}$ ) was extending along the northern boundary of the very moist $850 \mathrm{mb}$ air with the mixing ratio of $\sim 14 \mathrm{~g} / \mathrm{kg}$. At $700 \mathrm{mb}$, the zone of moist air (mixing ratio $\sim 10 \mathrm{~g} / \mathrm{kg}$ ), which is relevant to the convective cloud zone, was extending along $\sim 33^{\circ} \mathrm{N}$. The strong moisture inflow toward the convective cloud zone at $850 \mathrm{mb}$ was seen in the vicinity of the meso- $\alpha$-scale depression which was characterized by the fall of 850 and $700 \mathrm{mb}$ heights. It is also pointed out that the generation of the convective instability in the heavy rainfall area is not due to the cold-dry advection in the middle upper troposphere but mainly to the warmmoist advection in the lower troposphere.

From the aforementioned features, we will list up the followings as the important ones 
which we expect to simulate in the forecast experiment ;

(1) Concentration of intense precipitation.

(2) Formation of a meso- $\alpha$-scale depression to the east of the stationary synoptic-scale depression.

(3) Increase of the southwesterly and easterly winds to the south and north of the meso- $\alpha$-scale depression, and formation of mesoscale shear line around the north side of Kyushu.

(4) Generation of convective instability due to the low level warm-moist advection and the release of the generated convective instability in the heavy rainfall area.

(5) Low level moisture convergence toward the heavy rainfall area.

(6) Formation of the middle level moist zone relevant to the convective cloud zone.

\section{Description of experiment and model}

\subsection{Purposes and outline of experiments}

The main purposes of the experiments are as follows;

(1) To examine the prediction performance of very-fine-mesh primitive equation model for the case of extremely intense and concentrated rainfall.

(2) To examine the impact of increased resolution of the model on the prediction of the rainfall.

(3) To study the features and evolution process of the meso- $\alpha$-scale disturbance or circulation system which is thought to be related to the rainfall on the basis of the experimental results. The results of the experiment will cover, to some extent, insufficiency of the observational study.

(4) To evaluate the effect of diabatic heating due to the condensation on the evolution of the meso- $\alpha$-scale disturbance or circulation system.

For these purposes, we made forecast experiment from the initial data at 12 GMT 22, 00 GMT 23 and 12 GMT 23 July 1982 using the models listed in Table 1.

\subsection{Models in the present study}

The primitive equation models used in the present study are listed in Table 1. The vertical structure of these models and the physical processes included in them are given in Fig. 6 and Table 2 respectively.

The 10L FM127 is a fine-mesh and limited area version of $8 \mathrm{~L} \mathrm{NHM}$ and one-way nested in 8L NHM. All 13L VFM42, 11L VFM42 and 11L VFM63 are the very-fine mesh version of 10L FM127 and one-way nested in 10L FM127. These models adopt an economical explicit time integration scheme proposed by

Table 1 Primitive equation models used in the present study.

\begin{tabular}{|c|c|c|c|c|c|}
\hline model & 13L VFM42 & 11L VFM42 & 11L VFM63 & 10L FM27 & 8L NHM \\
\hline grid size at $60 \mathrm{~N}$ & $42 \mathrm{~km}$ & $42 \mathrm{~km}$ & $63 \mathrm{~km}$ & $127 \mathrm{~km}$ & $381 \mathrm{~km}$ \\
\hline number of levels & 13 & 11 & 11 & 10 & 8 \\
\hline top of the model & $100 \mathrm{mb}$ & $100 \mathrm{mb}$ & $100 \mathrm{mb}$ & $100 \mathrm{mb}$ & $30 \mathrm{mb}$ \\
\hline domain & limited area & limited area & limited area & limited area & $\begin{array}{l}\text { northern hemi- } \\
\text { sphere }\end{array}$ \\
\hline $\begin{array}{l}\text { boundary condi- } \\
\text { tion }\end{array}$ & $\begin{array}{l}\text { nested in } \\
\text { 10L-FM127 }\end{array}$ & $\begin{array}{l}\text { nested in } \\
\text { 10L-FM127 }\end{array}$ & $\begin{array}{l}\text { nested in } \\
\text { 10L-FM127 }\end{array}$ & $\begin{array}{l}\text { nested in } \\
\text { 8L-NHM }\end{array}$ & wall condition \\
\hline $\begin{array}{l}\text { objective analysis } \\
\text { system }\end{array}$ & $254 \mathrm{~km}$ & $254 \mathrm{~km}$ & $254 \mathrm{~km}$ & $254 \mathrm{~km}$ & $381 \mathrm{~km}$ \\
\hline integration & 24 hours & 24 hours & 24 hours & 36 hours & 48 hours \\
\hline use in JMA & $\begin{array}{l}\text { experimental } \\
\text { use }\end{array}$ & $\begin{array}{l}\text { experimental } \\
\text { use }\end{array}$ & $\begin{array}{l}\text { operational } \\
\text { use in } 1983\end{array}$ & $\begin{array}{l}\text { operational } \\
\text { use in } 1982\end{array}$ & $\begin{array}{l}\text { operational } \\
\text { use in } 1982\end{array}$ \\
\hline references & \multicolumn{3}{|c|}{ Staff members of ECC, JMA (1983) } & Tatsumi (1983) & Takigawa (1983) \\
\hline
\end{tabular}


Table 2 Physical processes.

\begin{tabular}{|c|c|c|c|c|}
\hline & NHM 381 & FM 127 & VFM 63 & VFM 42 \\
\hline $\begin{array}{l}\text { large scale conden- } \\
\text { sation }\end{array}$ & c.r.h. $100 \%$ & c.r.h. $100 \%$ & c.r.h. $100 \%$ & $\begin{array}{l}\text { (1) c. r. h. } 100 \% \\
\text { (2) no condensation }\end{array}$ \\
\hline dry convection & conv. adjustment & conv. adjustment & & \\
\hline moist convection & $\begin{array}{l}\text { conv. adjustment } \\
\text { (lowest } 4 \text { layer) }\end{array}$ & conv. adjustment & conv. adjustment & $\begin{array}{l}\text { (1) conv. adjust- } \\
\text { ment } \\
\text { (2) no }\end{array}$ \\
\hline vertical diffusion & $\begin{array}{l}\mathrm{K} \text { theory } \\
\mathrm{K}=10 \mathrm{~m}^{2} \mathrm{~s}^{-2} \\
\text { (lowest } 2 \text { layer) }\end{array}$ & $\begin{array}{l}\text { K theory depend- } \\
\text { ent on vertical } \\
\text { wind shear, } \\
\text { static stability } \\
\text { (lowest } 3 \text { layer) }\end{array}$ & \multicolumn{2}{|c|}{$\begin{array}{l}\text { level } 2 \text { closure model } \\
\text { (whole layer) }\end{array}$} \\
\hline $\begin{array}{l}\text { surface flux } \\
\text { (heat water vapor) }\end{array}$ & $\begin{array}{l}\text { bulk method } \\
\text { land ; } 0 \\
\text { sea; } C=0.002\end{array}$ & $\begin{array}{l}\text { bulk method } \\
\text { land ; } 0 \\
\text { sea; Kondo's for- } \\
\text { mula (1975) }\end{array}$ & \multirow{2}{*}{\multicolumn{2}{|c|}{$\begin{array}{l}\text { similarity theory } \\
\text { (over sea and land) } \\
\text { include radiation to } \\
\text { calculate fluxes over } \\
\text { land }\end{array}$}} \\
\hline $\begin{array}{l}\text { surface flux } \\
\text { (momentum) }\end{array}$ & $\begin{array}{l}\text { bulk method } \\
\text { land ; } c=0.0043 \\
\text { sea; } c=0.002\end{array}$ & $\begin{array}{l}\text { bulk method } \\
\text { land; c=0.0043 } \\
\text { sea; Kondo's for- } \\
\text { mula (1975) }\end{array}$ & & \\
\hline
\end{tabular}

Vertical structure

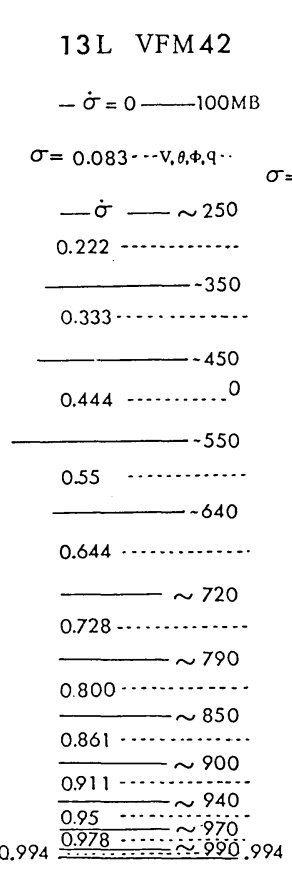

$11 \mathrm{~L}$ VFM 63

$11 \mathrm{~L}$ VFM 42

$-\dot{\sigma}=0 \longrightarrow 100 \mathrm{MB}-\dot{\sigma}=0 \longrightarrow 100 \mathrm{MB}$

$\sigma=0.056: \mathrm{v}, \theta, \phi, q \ldots \ldots$.

$-\dot{\sigma} \longrightarrow 200$

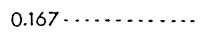

$-\dot{\sigma}-\sim 300$

$0.333 \ldots \ldots \ldots$

$\sim 500$
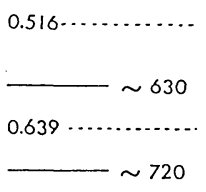

$0.728 \ldots \ldots \ldots \ldots . .$.

$\longrightarrow \sim 790$

$0.800 \ldots . . . . . .$.

$\overline{0.861 \cdots} \sim 850$

$0.861 \cdots \cdots \cdots \cdots \cdots$

$0.911 \cdots \ldots \ldots 900$

$0.95 \quad \cdots \ldots \ldots 940$

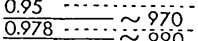

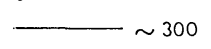

$0.278 \ldots \ldots \ldots \ldots$.

$\longrightarrow \sim 400$

$0.389 \ldots \ldots \ldots \ldots . .$.

$\sim 500$

$0.5 \ldots \ldots \ldots \ldots . . . .$.

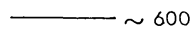

0.611

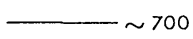

$0.722 \cdots \cdots \cdots \cdots$

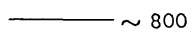

0.833

$\longrightarrow \sim 900$

$0.922 \cdots \cdots \ldots \ldots$

$\overline{0.978-2 \sim 960}$

\section{$8 \mathrm{~L} \quad \mathrm{NHM}$}

$$
-\dot{\sigma}=0-30 \mathrm{MB}
$$

$\sigma=0.0129 \cdots v_{,}, \phi, \cdots$

- $\dot{\sigma} \longrightarrow \sim 55$

$.0 .049 \ldots \ldots . . . .$.

$\sim \sim 100$

$-0.124 \cdots \cdots \cdot \ldots \cdot \ldots$

$\sim 200$

$\cdot 0.265 \cdots \cdots \cdots \cdot \cdots$

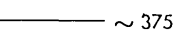

$0.446 \cdots \cdots \cdot \cdots$

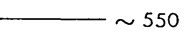

$0.626 \ldots . \cdots \cdot \cdots \cdot$

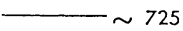

$0.807 \ldots \ldots . .+\cdots$

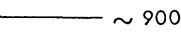

$0.948 \cdots \cdots, q \cdots$ $\sim 1000$

Horizontal structure

\begin{tabular}{|l|l|l|l|l|}
\hline $13 \mathrm{~L}$ VFM 42 & $11 \mathrm{~L}$ VFM42 & $11 \mathrm{~L}$ VFM63 & 10L FM 127 & $8 \mathrm{~L}$ NHM \\
\hline Arakawa B-type & Arakawa B-type & Arakawa A-type & Arakawa B -type & Arakawa B-type \\
\hline$d=42.3 \mathrm{~km}(73 \times 61)$ & $d=12.3 \mathrm{~km}(73 \times 61)$ & $d=63.5 \mathrm{~km}(55 \times 55)$ & $d=127 \mathrm{~km}(73 \times 55)$ & $d=38 \mathrm{~km}(65 \times 65)$ \\
\hline
\end{tabular}

Fig. 6 Vertical structure of the models used in the present study. 
Tatsumi (1983).

We shall explain about experiments (1) and (2) by 13L VFM42 listed in Table 2 . The standard experiment, i.e., the version (1), adopts the conventional moist convective adjustment scheme. Neither the large-scale condensation nor the moist convective adjustment scheme are included in the version (2). The version (2) is therefore called as "dry experiment" hereafter in the present paper.

We will describe very briefly the topography in the 13L VFM42. The height of the model mountain in the central part of Japan is about $1100 \mathrm{~m}$ while that in Kyushu is about $400 \mathrm{~m}$ above the sea level. Although characteristic topography of the Japan Islands is included in the model, the fine topography such as the Nagasaki Peninsula, some small coastal mountain range, which may be important for the occurrence of the rainfall, are not included in the model.

The more detailed description and explanation on these models are given in the references listed in Table 1.

\section{Forecast experiment by 13L VFM42}

We examine the results of 24-hour forecast experiment by the version (1) of 13L VFM42 from the initial states at 12 GMT 22 and 00 GMT 23 July 1982.

\section{Results for 12 GMT 23 July 1982}

The model does not produce much rainfall during the earlier 12-hour period of the integration. Because the horizontal spacing of the upper observation stations is $300 \sim 500 \mathrm{~km}$, the subsynoptic-scale variations are not accurately included in the objectively analyzed initial state. The model took several hours to generate the mesoscale circulation from the somewhat smoothed intial field. This will be the reason why the model produces the large precipitation only in the later 12-hour period of the integration.

Fig. 7 shows the predicted 6-hour precipitation for $06 \sim 12$ GMT 23 and the vertical $p$-velocity at $700 \mathrm{mb}\left(\omega_{700}\right)$ for 12 GMT 23 July 1982. The strong rainfall (maximum amount $\sim 70 \mathrm{~mm} / 6$ hour*) is predicted over the northern part of Kyushu, where the intensive
I2 GMT 23 JUL 1982 (18 24 h) RAIN

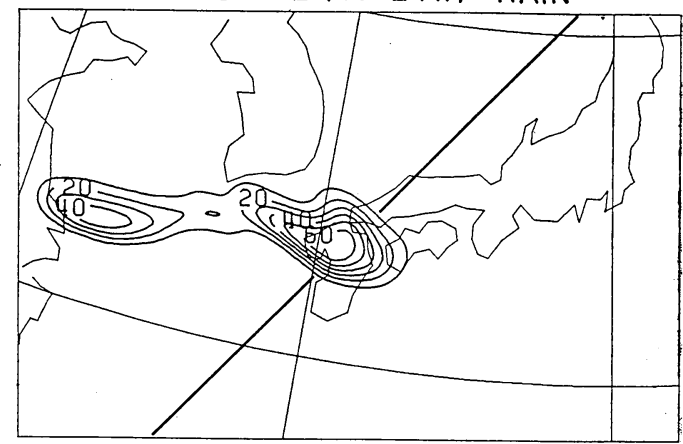

I2 GMT 23 JUL $1982(24 \mathrm{~h}) \omega_{700}$

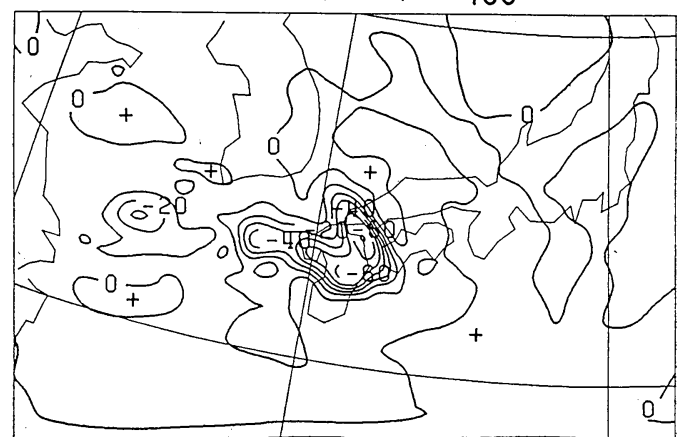

Fig. 7 Predicted 6-hour precipitation ( $\mathrm{mm} / 6$ hour) for $06 \sim 12$ GMT 23 and vertical $p$-velocity at $700 \mathrm{mb}$ (mb/hour) for 12 GMT 23 July 1982. The vertical cross section along the thick solid line in the precipitation map is shown in Fig. 13.

rainfall was observed. Although the predicted precipitation is much smaller than the maximum observed precipitation, the location of the rainfall area and its concentration are accurately simulated. The vertical $p$-velocity at $700 \mathrm{mb}$ over the area of maximum rainfall is about $-60 \mathrm{mb} /$ hour. We also see a zone of rainfall ( $\sim 10 \mathrm{~mm} / 6$ hour) extending over the East China Sea, where the zone of low $T_{B B}$ clouds were observed by the satellite (cf. Fig. 3).

Fig. 8 and Fig. 9 show the predicted 850 $\mathrm{mb}$ height and wind for 00 GMT and 12 GMT 23 July 1982. The height contour (solid line) is given at $15 \mathrm{~m}$ interval. The broken lines are the isolines of $850 \mathrm{mb}$ height change in the preceeding 12-hour. There is an area of maximum height fall $(-30 \mathrm{~m} / 12$ hour $)$ to the north of Kyushu, where the maximum height

* Predicted precipitation accumulated for the 6-hour period. 
OO GMT 23 JUL $1982(12 \mathrm{~h}) \quad \mathrm{Z}_{850}$

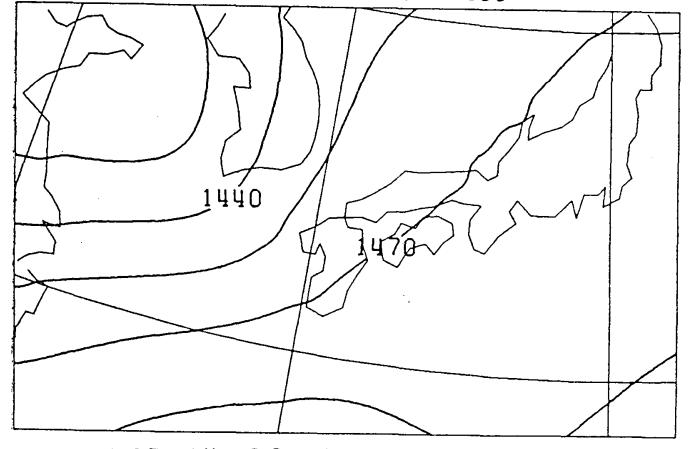

12 GMT 23 JUL $1982(24 \mathrm{~h}) \quad \mathrm{Z}_{850}, \Delta \mathrm{Z}_{850}$

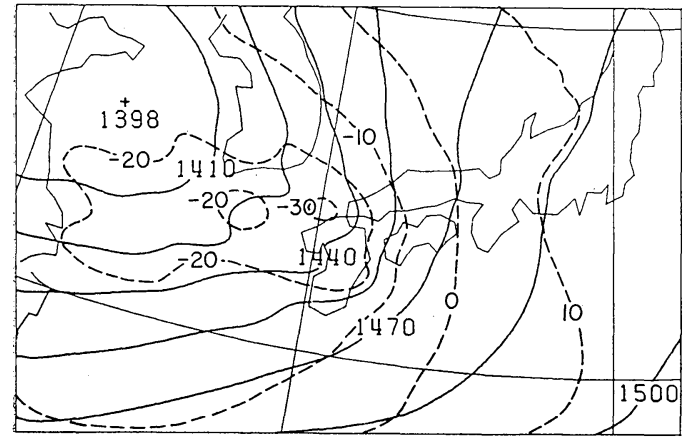

Fig. 8 Predicted $850 \mathrm{mb}$ height for 00 GMT 23 and 12 GMT 23 July 1982. The height contour (solid line) is given at $15 \mathrm{~m}$ interval. The broken lines are isolines of $850 \mathrm{mb}$ height change in the preceding 12-hour. The numeral in ( ) indicates the integration time from the initial.

fall of about $-80 \mathrm{~m}$ /day was observed. It is noted, however, that the predicted height fall is not strongly concentrated in a meso- $\alpha$-scale area as was actually observed (Fig. 4). Concurrent with the height fall, the southwesterly ( $\sim 15 \mathrm{~m} / \mathrm{sec})$, southerly $(\sim 15 \mathrm{~m} / \mathrm{sec})$ and southeasterly $(\sim 10 \mathrm{~m} / \mathrm{sec})$ winds are enhanced to the southwest, southeast and northeast of the area of maximum height fall, and the shear line and meso- $\alpha$-scale cyclonic circulation are formed around Kyushu. The predicted wind speed is, however, smaller than the observed speed by $\sim 5 \mathrm{~m} / \mathrm{sec}$ around the intense rainfall area.

The predicted mixing ratios at $850 \mathrm{mb}$ and $700 \mathrm{mb}$ for 12 GMT 23 are presented in Fig. 10. The zone of high mixing ratio $\left(q_{850} \approx 16 \mathrm{~g}\right.$ $/ \mathrm{kg}$ and $q_{700} \approx 12 \mathrm{~g} / \mathrm{kg}$ ) extends over the East China Sea where the zone of the low $T_{B B}$ cloud was observed. It is seen that at $700 \mathrm{mb}$

\section{O0 GMT 23 JUL $1982(12 h) \quad \mathbb{V} 850$}

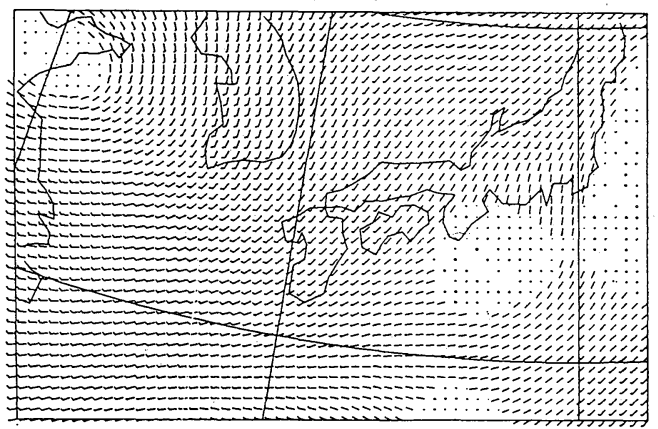

I2GMT 23 JUL $1982(24 h) \quad V_{850}$

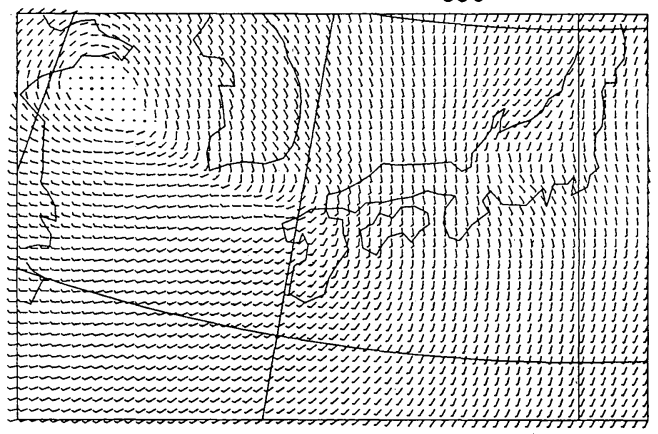

Fig. 9 Predicted wind field at $850 \mathrm{mb}$ for $00 \mathrm{GMT}$ and 12 GMT 23 July 1982 . A full wind berb indicates $10 \mathrm{~m} / \mathrm{sec}$ (20 knot).

12 GMT 23 JUL $1982(24 \mathrm{~h}) \quad q_{850}$

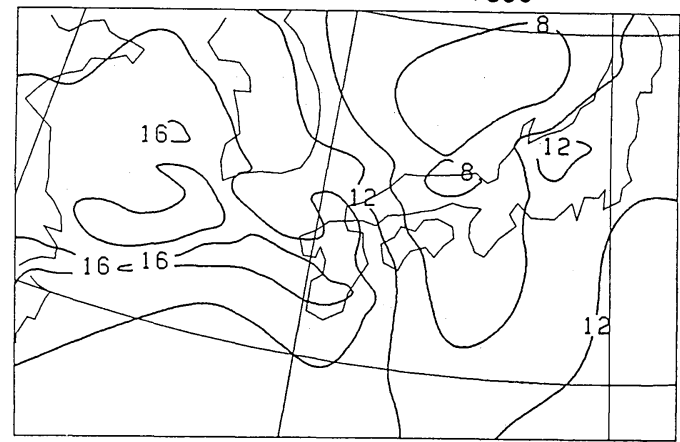

12 GMT 23 JUL 1982 (24h) q 700

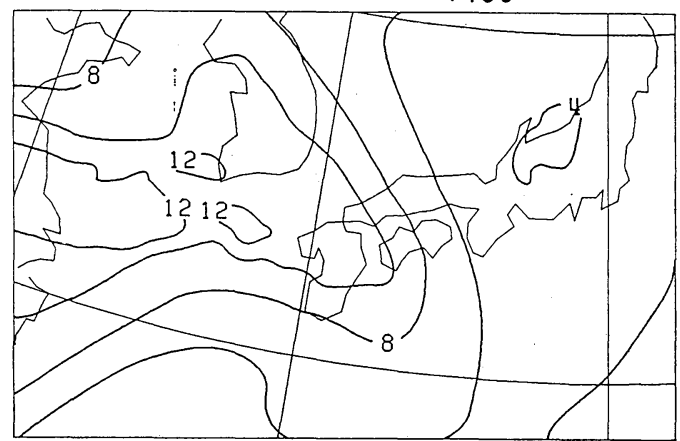

Fig. 10 Predicted mixing ratios at $850 \mathrm{mb}$ and $700 \mathrm{mb}$ for 12 GMT 23 July 1982. 
the area of relatively dry air $\left(q_{700} \approx 6 \sim 8 \mathrm{~g} / \mathrm{kg}\right)$ spreads to the south of the precipitation zone. These features of the predicted moisture field agree with the observed moisture field (see Fig. 5).

Fig. 11 shows the predicted water vapor flux $(\boldsymbol{V} q)$ at $900 \mathrm{mb}$ and $700 \mathrm{mb}$ for $12 \mathrm{GMT}$ 23 July 1982. At $900 \mathrm{mb}$, large moisture flux was predicted to the south of the precipitation zone and the largest flux convergence of the moisture is seen just along the precipitation zone around Kyushu. At $700 \mathrm{mb}$, the large moisture flux is seen over the precipitation zone. We will examine again the field of moisture flux from the view point of the water budget of intense rainfall in the latter section.

The vertical cross sections of predicted wind, equivalent potential temperature (thin solid line), mixing ratio (thin broken line) for 12 GMT 23 July 1982, and diabatic heating in the preceding 6-hour (thick solid line) along the thick line in Fig. 7 (predicted precipita-
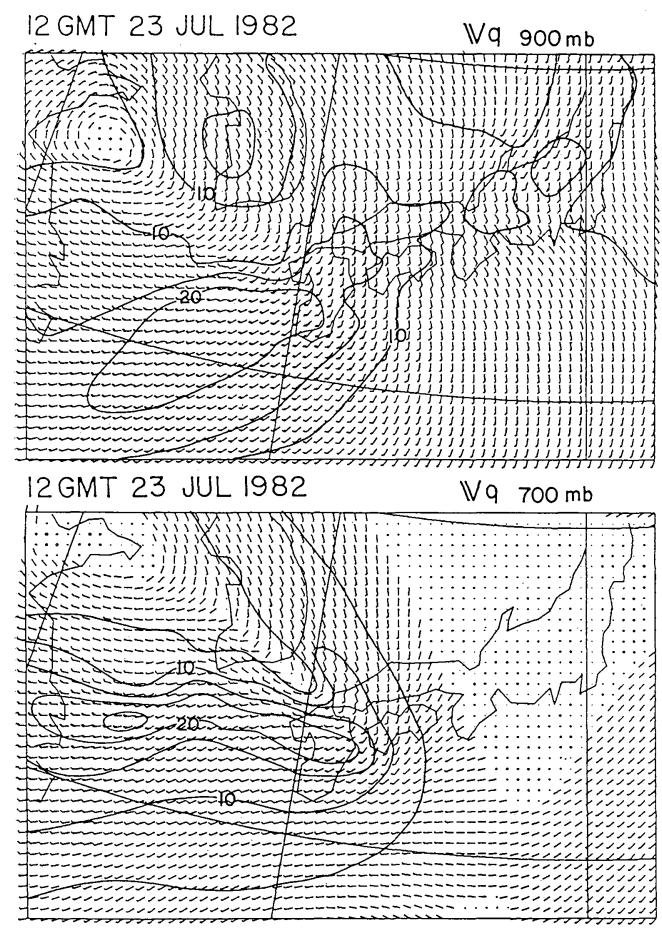

Fig. 11 Predicted water vapor flux $(\boldsymbol{V} q)$ at 900 $\mathrm{mb}$ and $700 \mathrm{mb}$ for 12 GMT 23 July 1982 . A wind berb indicates $(100 \mathrm{~m} / \mathrm{sec})(\mathrm{g} / \mathrm{kg})$. The isolines is for $|\boldsymbol{V}| q$, unit is in $(10 \mathrm{~m} / \mathrm{sec})$ $(\mathrm{g} / \mathrm{kg})$.
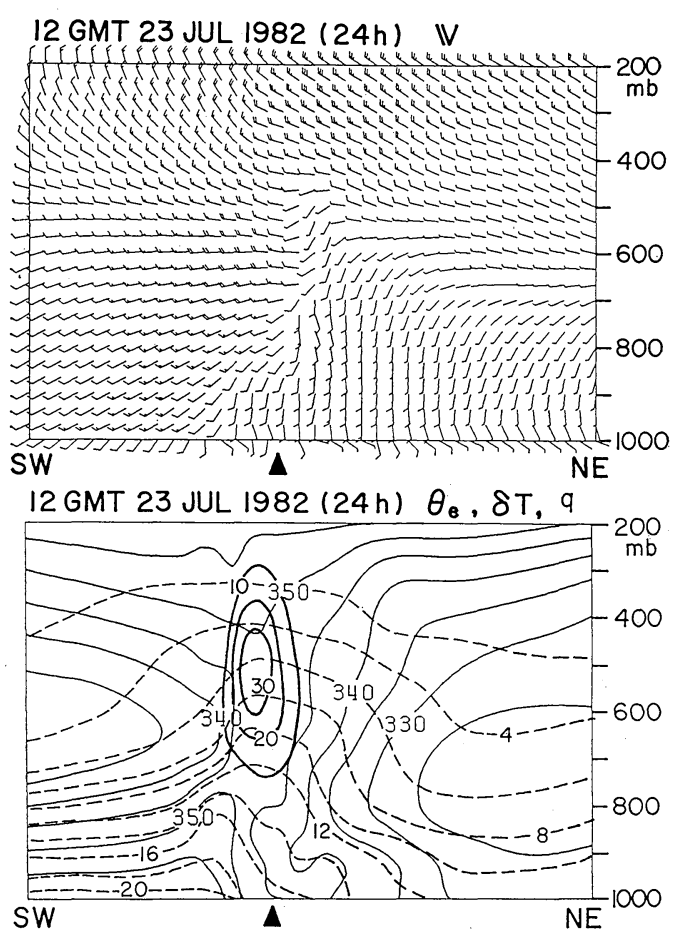

Fig. 12 Vertical cross section of predicted wind (a full wind berb indicates $10 \mathrm{~m} / \mathrm{sec}$ ), equivalent potential temperature $\left(\theta_{e}\right.$; solid line, $\left.{ }^{\circ} \mathrm{K}\right)$, mixing ratio $(q$ : broken line, $\mathrm{g} / \mathrm{kg})$ and diabatic heating in the preceding 6 -hour $(\delta T$ : thick line, ${ }^{\circ} \mathrm{K} / 6$ hour) along the thick solid line in the precipitation map in Fig. 7. The distance between the grid in this figure is $42 \times \sqrt{2} \mathrm{~km}(\sim 60 \mathrm{~km})$.

tion map) are presented in Fig. 12. On the vertical cross section, the area of intense rainfall is indicated by mark. There is a distinct wind shear zone between the southwesterly wind to the west of the rainfall area and southerly wind to the east of the rainfall area. The feature of $\theta_{e}$ field is also interesting. There are convectively unstable layer (i.e., $\theta_{e 900} \approx 355 \mathrm{~K}$ and $\theta_{e r 00} \approx 340 \mathrm{~K}$ ) to the south of the rainfall area, while the nearly moist neutral layer $\left(\theta_{e} \approx 350 \mathrm{~K}\right)$ with high mixing ratio is formed in the intense rainfall area. The layer of large diabatic heating $(20 \mathrm{~K} / 6$ hour) is also seen in the middle troposphere in this moist neutral layer. This diabatic heating is mainly due to the process of the large-scale condensation and moist convective adjustment of the model. The strong diabatic 
heating was mainly compensated by $\omega(\partial \theta / \partial p)$ and therefore the predicted $\partial T / \partial t$ is very smaller than the diabatic heating.

Results for 00 GMT 24 July 1982

Fig. 13 is the map of predicted precipitation for 18 GMT 23 00 GMT 24 July 1982. The

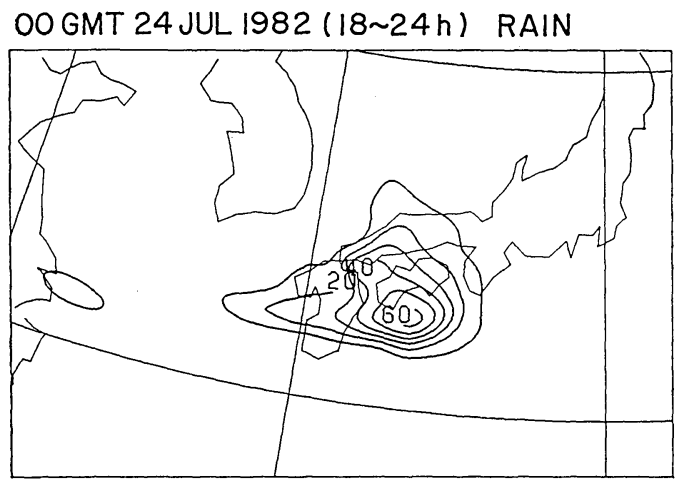

Fig. 13 Predicted 6-hour precipitation for 18 GMT 23 00 GMT 24 July 1982.

OO GMT 24 JUL $1982(24 h) \quad Z 850, \Delta Z 850$

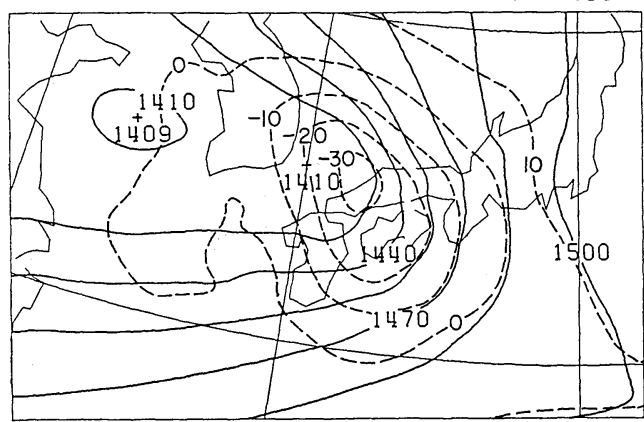

OOGMT 24 JUL $1982(24 h) \quad V_{850}$

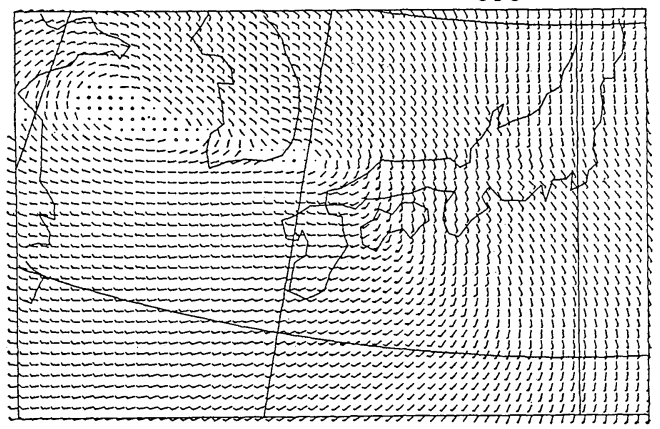

Fig. 14. Predicted $850 \mathrm{mb}$ height (solid line) and wind for 00 GMT 24 July 1982 and $850 \mathrm{mb}$ height change in the preceding 12-hour (broken line). large amount of precipitation (maximum $\sim 60$ $\mathrm{mm} / 6$ hour) is predicted to the south of Shikoku. At $00 \mathrm{GMT} 24$, the satellite observed an area of low cloud $\left(\sim-60^{\circ} \mathrm{C}\right)$ to the east of Kyushu to the south of Shikoku.

The predicted $850 \mathrm{mb}$ height and wind for 00 GMT 24 and $850 \mathrm{mb}$ height change in the preceding 12-hour (broken line) are presented in Fig. 14. The meso- $\alpha$-scale area of $850 \mathrm{mb}$ height fall and wind shear line are predicted in the location relevant to the observed locations. The $850 \mathrm{mb}$ height change ( - $30 \mathrm{~m} /$ 12 hour) is slightly larger compared to the observation.

\section{Discussion}

The predicted precipitation rate for 06 GMT $\sim 12$ GMT 23 ( $\sim 70 \mathrm{~mm} / 6$ hour) is nearly equal to that for GMT 23 00 GMT $24(\sim 60 \mathrm{~mm} / 6$ hour), although the observed precipitation rate was extremely large in the earlier period. The predicted "mes $2-\alpha$-scale isallobaric low at 850 $\mathrm{mb}$ " and "meso- $\alpha$-scale circulation system" for 00 GMT 24 are more predominant than those predicted for 12 GMT 23, while the observed isallobaric low and circulation system are most evident at 12 GMT 23.

As a whole, the model underestimates the precipitation and the development of the meso$\alpha$-scale system in the earlier period of the evolution. The present model can not predict accurately its evolution from the early stages (12 GMT 22). On the other hand, the model predict the evolution properly from the initial state at 00 GMT 23, when the system had grown to some extent.

\section{Effect of increased grid resolution on the mesoscale system and precipitation}

\subsection{Effect of increased horizontal grid resolution}

We examine effect of the increased horizontal grid resolution of model on the predicted precipitation. The predicted precipitation for 06 12 GMT 23 and 18 GMT 23 00 GMT 24 July 1982 by 10L FM127 are presented in Fig. 15 (isohyets are at $5 \mathrm{~mm} / 6$ hour interval). Comparing the predictions by $13 \mathrm{~L}$ VFM42 (Fig. 7 and Fig. 13, isohyets are at $10 \mathrm{~mm} / 6$ hour interval) with Fig. 15, we find that the 
12 GMT 23 JUL 1982 FMI27 6hour RAIN

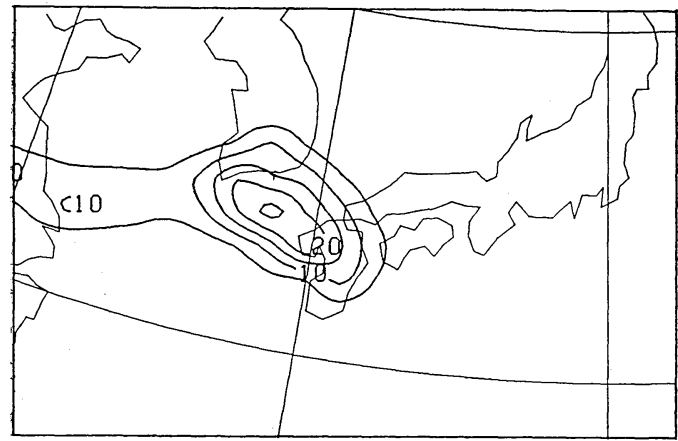

OOGMT 24 JUL 1982 FM 127 6hour RAIN

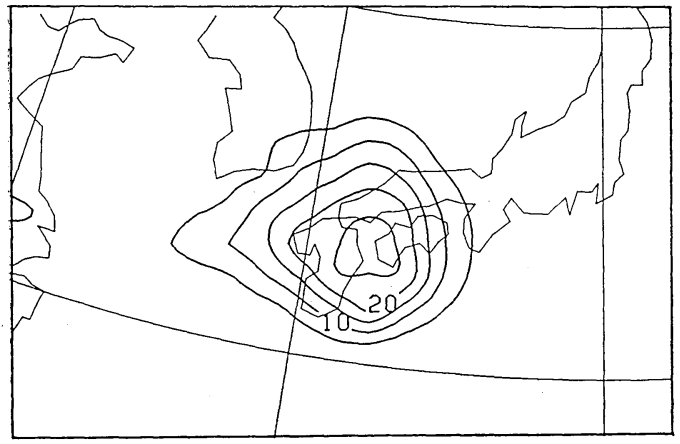

Fig. 15 Predicted precipitation for $06 \sim 12$ GMT 23 and 18 GMT 23 00 GMT 24 July 1982 by 10L FM127.

precipitation predicted by $10 \mathrm{~L}$ FM127 is much smaller and less concentrated than that by 13L VFM42.

For the more quantitative examination, we compare the precipitation predicted by the models listed in Table 1 for three periods of 06 12 GMT 23, 18 GMT 23 00 GMT 24 and 06 12 GMT 24 July 1982. Table 3 shows the percentage ratio of the area of the different precipitation rate to the total area of $(3 \times 381$ $\mathrm{km})^{2}$. It is seen that the intense precipitation

Table 3 The percentage ratio of area of the different precipitation rate $(\mathrm{R}: \mathrm{mm} / 6$ hour) to the total area of $(3 \times 381 \mathrm{~km})^{2}$.

\begin{tabular}{ccccc}
\hline $\mathrm{R} \mathrm{mm} / 6 \mathrm{~h}$ & $\mathrm{NHM}$ & $\mathrm{FM} 127$ & $\mathrm{VFM} 63$ & $\mathrm{VFM} 42$ \\
\hline 0 & 15 & 53 & 51 & 52 \\
$1 \sim 9$ & 85 & 42 & 29 & 27 \\
$10 \sim$ & & 5 & 8 & 9 \\
$20 \sim$ & & & 5 & 6 \\
$30 \sim$ & & & 4 & 3 \\
$40 \sim$ & & & 2 & 2 \\
$50 \sim$ & & & 1 & 1 \\
\hline
\end{tabular}

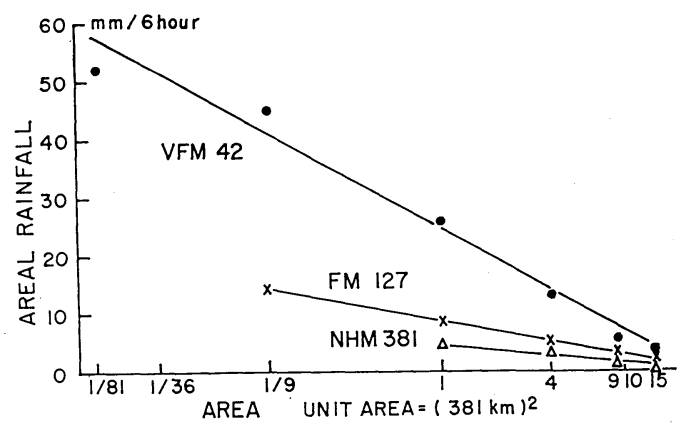

Fig. 16. The areal averaged predicted precipitation rate by $13 \mathrm{~L}$ VFM42, $10 \mathrm{~L}$ FM127 and $8 \mathrm{~L}$ NHM381 for the various areas. The ordinate shows the areal averaged precipitation rate and abscissa shows the dimension of area in which the averaged precipitation rate are calculated.

concentrated in narrow area is predicted by 13L VFM42 and 11L VFM63.

It is an interesting question whether the increase of grid resolution works only to concentrate precipitation or also works to increase the total (areal integrated) precipitation. Fig. 16 shows the areal mean precipitation for the various areas obtained by $13 \mathrm{~L}$ VFM42, 10L FM127 and 8L NHM381. It is evident that the increase of the grid resolution works not only to concentrate the precipitation but also to increase the total amount of precipitation.

Then, the next question, why and how the total amount of precipitation is increased and from where the water vapor is supplied to feed the increased precipitation, is aroused. To examine these problem, we examine the predictions by $10 \mathrm{~L}$ FM127. The predicted 850 $\mathrm{mb}$ height, wind, mixing ratio and $900 \mathrm{mb}$ moisture flux $(\boldsymbol{V} q)$ for 12 GMT 23 July by $10 \mathrm{~L}$ FM127 are presented in Fig. 17 and Fig. 18. Some significant differences between 13L VFM42 and 10L FM127 are found in the lowlevel wind velocity and the moisture flux in and around the heavy rainfall area. To the southwest of Kyushu, the velocity of low-level southwesterly wind 10L FM127 is much smaller than that in 13L VFM42. To the northwest of Kyushu, the easterly component of the low-level wind velocity in 10L FM127 is much smaller than that in 13L VFM42 while the southerly component in 10L FM127 is large than that in 13L VFM42. In short, the shear 


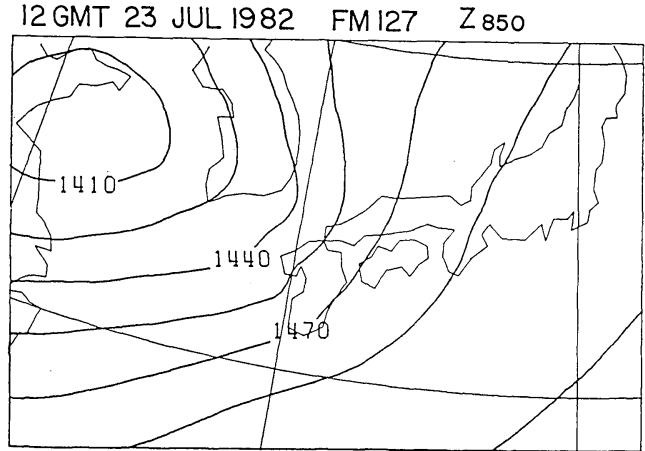

12 GMT 23 JUL 1982 FMI27 $\mathbb{V}_{850}$

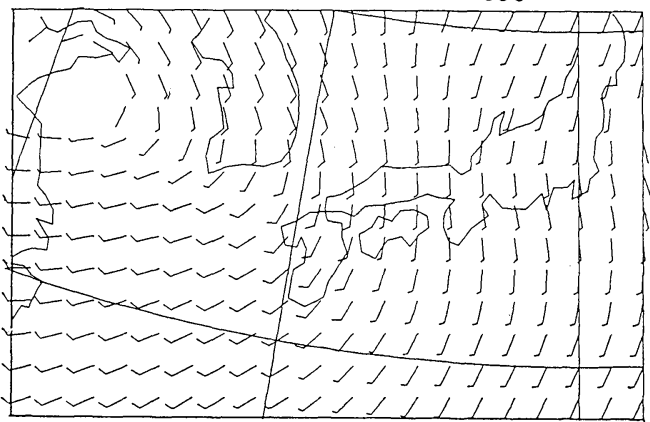

Fig. 17. Predicted $850 \mathrm{mb}$ height and wind for 12 GMT 23 July 1982 by 10L FM127.

\section{GMT 23 JUL 1982 FM 127 q 850}

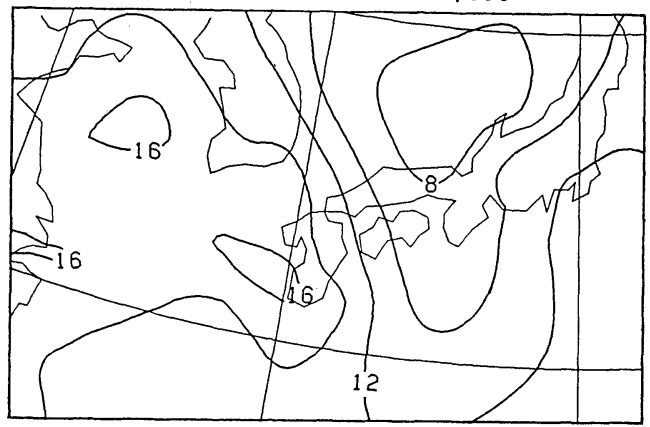

I2 GMT 23 JUL 1982 FM 27 IVq $900 \mathrm{mb}$

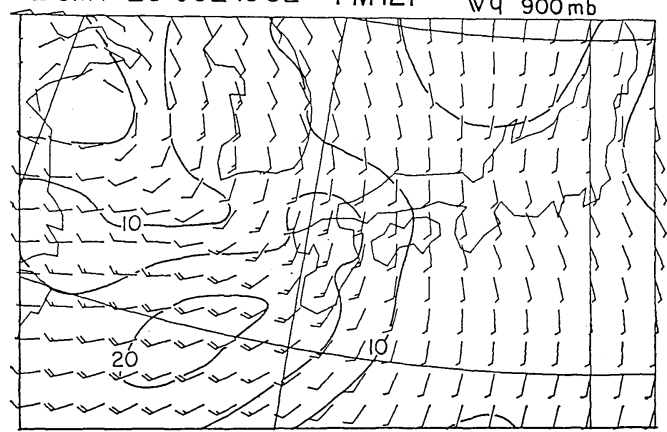

Fig. 18 Predicted $850 \mathrm{mb}$ mixing ratio and $900 \mathrm{mb}$ moisture flux (unit in $10(\mathrm{~m} / \mathrm{s})(\mathrm{g} / \mathrm{kg})$ ) for 12 GMT 23 July 1982 by 10L FM127. and convergence line is much intensified in 13L VFM42 as compared with that in $10 \mathrm{~L}$ FM127 (compare $\boldsymbol{V}_{850}$ in Fig. 9 with that in Fig. 17).

To the southwest of Kyushu, the low-level moisture flux (northeastward) in 10L FM127 is smaller than that in 13L VFM42 (compare the area enclosed by the isoline of $|\boldsymbol{V}| q_{900}$ labeled by 20 in Fig. 11 with that in Fig. 18). In 10L FM127, relatively large amount of moisture is transported toward north across the heavy rainfall zone (see the isoline of $|\boldsymbol{V}| q_{900}$ labeled by 10 in Fig. 18), while the moisture flux is minimized to the north of the heavy rainfall zone in 13L VFM42 (see the isoline of $|\boldsymbol{V}| q_{900}$ labeled by 10 in Fig. 11). In short, the low-level moisture influx toward the heavy rainfall zone from the south is enhanced and the efflux from the heavy rainfall zone toward north is suppressed in 13L VFM42 and the moisture convergence is concurrently intensified.

The low-level moisture content around the heavy rainfall zone of 13L VFM42 is smaller than that of 10L FM127 (see the isoline of $q_{850}$ labeled by $14 \mathrm{~g} / \mathrm{kg}$ in Fig. 10 and Fig. 18). This difference in the moisture field is resulted from the difference in the moisture transport between these models. The 13L VFM42 produces the more large precipitation by consuming the more large amount of low-level moisture around the heavy rainfall zone as compared with 10L FM127.

\subsection{Effect of increased vertical grid resolution}

The vertical resolution of 11L VFM42 and 11L VFM63 are relatively high in the lower troposphere but relatively low in the middle upper troposphere (see Fig. 6). In these models, we have 7 levels in the lower troposphere below $\sim 700 \mathrm{mb}$ and only 4 levels in the middle $\sim$ upper troposphere above $\sim 700 \mathrm{mb}$, since we thought first that higher vertical resolution in the lower layer is most important to simulate small-scale phenomena. The experiments by 11L VFM42 and 11L VFM63 showed some small-scale $(2 \sim 4$ grid size) noises occurred in and around the heavy rainfall area. These noises are thought to be generated through 
the diabatic processes such as the moist convective adjustment and large-scale condensation in the model. In expectation of reducing the noises, we take 6 levels in the middle upper troposphere in 13L VFM42. As was expected, the noises are considerably reduced in 13L VFM42.

It was also found that the prediction of the meso- $\alpha$-scale depression and circulation system is significantly improved by $13 \mathrm{~L}$ VFM42 as compared with the prediction by 11L VFM42. That is, the $850 \mathrm{mb}$ height change of the meso- $\alpha$-scale depression predicted by $13 \mathrm{~L}$ VFM 42 is $\sim 30 \mathrm{~m} / 12$ hour while that by $11 \mathrm{~L}$ VFM 42 is $\sim 20 \mathrm{~m} / 12$ hour. The maximum precipitation of $\sim 60 \mathrm{~mm} / 6$ hour by $11 \mathrm{~L}$ VFM42 are also enhanced to $\sim 70 \mathrm{~mm} / 6$ hour by $13 \mathrm{~L}$ VFM42.

The comparison between the prediction by 13L VFM42 and that by 11L VFM42 indicates that the increases of the vertical resolution not only in the lower troposphere but also in the middle $\sim$ upper troposphere are important to improve the prediction of the heavy rainfalls and the related subsynoptic-scale circulation system.

\section{Effect of condensation heating on the meso- $\alpha$-scale circulation}

To evaluate the effect of condensation heating on the meso- $\alpha$-scale circulation in the heavy rainfall zone, we compare the prediction by the standard 13L VFM42, i.e., the version (1), with the prediction by the dry version, i.e., version (2). Fig. 19 shows the 24-hour prediction of $850 \mathrm{mb}$ height and wind for 12 GMT 23 July 1982 by the dry model. The broken lines are the isolines of $850 \mathrm{mb}$ height change in the preceding 12-hour. In the dry model, the height fall of $\sim 20 \mathrm{~m} / 12$ hour is predicted over the large-scale low over the Yellow Sea $\left(\sim 37^{\circ} \mathrm{N} / 121^{\circ} \mathrm{E}\right)$. The meso- $\alpha$ scale area of height fall which is predicted by the standard experiment around Kyushu is not seen in the dry model. The shear line, which is formed in the standard experiment (see Fig. 9), is not simulated in the dry experiment. The vertical- $p$-velocity in the dry model is $\sim-10 \mathrm{mb} /$ hour (figure is not present-
12GMT 23 JUL 1982 (24h) Z850 DRY EXP

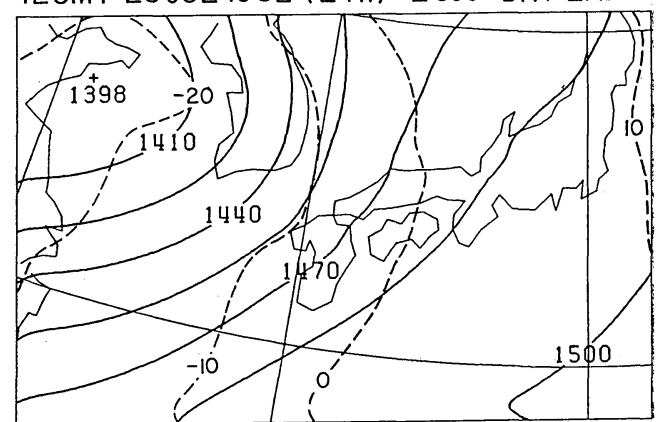

12GMT 23 JUL 1982(24h) V850 DRY EXP

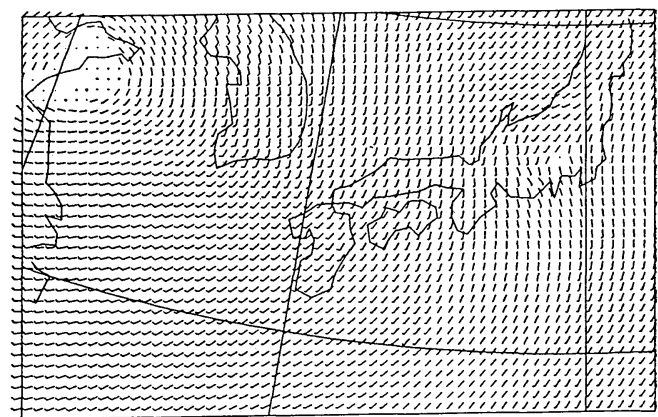

Fig. 19 Predicted $850 \mathrm{mb}$ height, height change in the preceding 12 -hour and wind by the dry experiment of 13L VFM42 for 12 GMT 23 July 1982.

ed) while that in the standard experiment is as much as $\sim-70 \mathrm{mb} /$ hour. The aforementioned comparison indicates that the condensation heating has great infiuence on the formation of the mesoscale circulation system in the heavy rainfall area.

We also know from the results in Section 5 that the influence of the condensation heating on the mesoscale circulation system becomes larger with the increase of the resolution of the model. As the resolution of the model increases, the condensation is more concentrated in smaller area, and the concentrated condensation heating works more effectively to intensify the mesoscale circulation system, and thus intensified circulation works further to concentrate the condensation and condensation heating. It is suggested that some feedback mechanism between the condensation and mesoscale circulation system plays some important role in the occurrence of heavy rainstorm. 


\section{Diagnostic studies of the heavy rain- storm using the output from the very- fine mesh primitive equation model}

In many cases, the spatial and temporal densities of the observation are not enough for the detailed diagnostic study of subsynoptic-scale disturbances. Therefore, the output from the very-fine-mesh primitive equation model is very useful as a data source for diagnostic study of subsynoptic-scale disturbances. In the present section, we will make diagnostic study on the generation of convective instability and moisture transport in the heavy rainfall area, and the kinematic feature of the meso- $\alpha$-scale circulation on the basis of the output from 13L VFM42.

\subsection{Generation of convective instability}

It is well known that the generation of convective instability through the differential thermal advection is one of the preferable conditions for the occurrence of intense convective precipitation. The time change of equivalent potential temperature $\left(\theta_{e}\right)$ due to the three dimensional advection $\left(\left(\partial \theta_{\tau} / \partial t\right)_{A D}\right)$ is

$$
\frac{\partial \theta_{e}}{\partial t} A D=-\boldsymbol{V} \nabla \theta_{e}-\omega \frac{\partial \theta_{e}}{\partial p}
$$

and therefore the time change of the convective instability due to the differential advection is

$$
\frac{\partial}{\partial t}\left(-\frac{\partial \theta_{e}}{\partial p}\right)_{A D}=\frac{\partial}{\partial p}\left(\boldsymbol{V} \nabla \theta_{e}+\omega \frac{\partial \theta_{e}}{\partial p}\right) .
$$

We examine the $\theta_{e}$-advection $\left(=-\boldsymbol{V} \nabla \theta_{e}-\right.$ $\left.\omega\left(\partial \theta_{e} / \partial p\right)\right)$ at each pressure surface. Fig. 20 shows $\left(\partial \theta_{e} / \partial t\right)_{A D}=-\boldsymbol{V} \nabla \theta_{e}-\omega\left(\partial \theta_{e} / \partial p\right)$ at 300 $\mathrm{mb}$ and $850 \mathrm{mb}$ for $12 \mathrm{GMT} 23$ July 1982 . At $300 \mathrm{mb}$, there is a zone of weak cold- $\theta_{e}$ advection over the East China Sea $\sim$ Kyushu area along $\sim 33^{\circ} \mathrm{N}$ latitude. The cold- $\theta_{e}$ advection in the upper troposphere, however, does not much contribute to generate the convective instability because its magnitude is small $(0 \sim$ $-1 \mathrm{~K} /$ hour) and there is also a zone of the cold- $\theta_{e}$ advection in the lower troposphere. On the one hand, the strong warm- $\theta_{e}$ advection more than $2 \mathrm{~K}$ /hour takes place just over Kyushu (see the hatched area in $850 \mathrm{mb}$ map

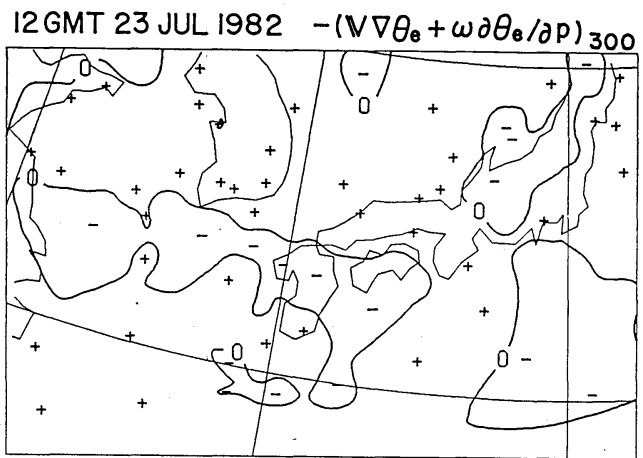

12 GMT 23JUL $1982-\left(\mathbb{V} \nabla \theta_{\theta}+\omega \partial \theta_{\theta} / \partial \mathrm{p}\right) 850$

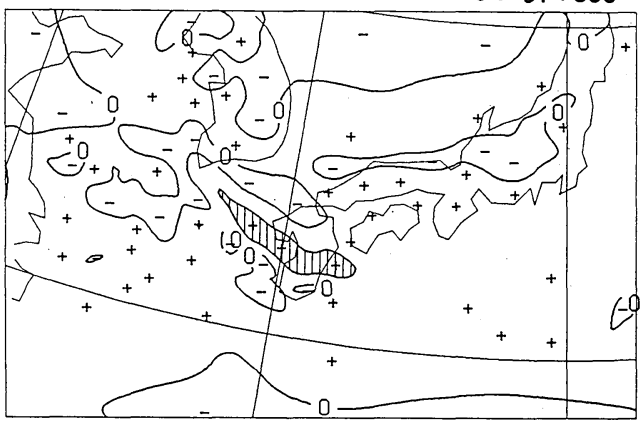

Fig. 20 Time change of equivalent potential temperature due to the three-dimensional advection at $300 \mathrm{mb}$ and $850 \mathrm{mb}$ for 12 GMT 23 July 1982 predicted by $13 \mathrm{~L}$ VFM42. The isoline of $-\left(\boldsymbol{V} \nabla \theta_{e}+\omega \partial \theta_{e} / \partial p\right)$ is givən at $2 \mathrm{~K}$ ! hour interval.

in Fig. 20). In short, the generation of the convective instability in the present case is not attributed to cold-dry advection in the upper troposphere but mainly to warm-moist advection in the lower troposphere.

The aforementioned features found from the model output agree with the observed features, although the observations are sparse compared with the model output. It is also pointed out in many studies (Akiyama, 1979; Ninomiya and Yamazaki, 1979) that the generation of convective instability in the heavy rainfall area within the Baiu front is mainly due to the warm-moist advection in the lower layers.

The strong convective instability thus generated is released in the heavy rainfall area. The strong diabatic (condensation) heating and the formation of thick layer with nearly moist neutral lapse rate (vertically approximately uniform $\theta_{e}$ ) seen in the vertical cross 
section (Fig. 12) indicate that the generation and the release of the convective instability is balanced by each other in the heavy rainfall area.

\subsection{Moisture convergence in the heavy rainfall area}

We have shown the wind and moisture flux field (Fig. 9 and Fig. 11) in and around the heavy rainfall area. Now we will examine the moisture convergence in a $17 \times 17$ grid ( 42 $\mathrm{km}$ grid) area including the heavy rainfall area using the model output for 12 GMT 23 July 1982. Fig. 21 shows vertical distribution of the moisture flux across the boundary (normal component of the flux to each side) of the $17 \times 17$ grid area. The northward moisture influx across the southern boundary of the area is approximately equal to the northward moisture eflux across the northern boundary. The eastward moisture influx across the western boundary in the lower layer is very large compared with the eastward eflux across the eastern boundary. The moisture convergence of the present case is mainly due to the convergence between the southwesterly wind the

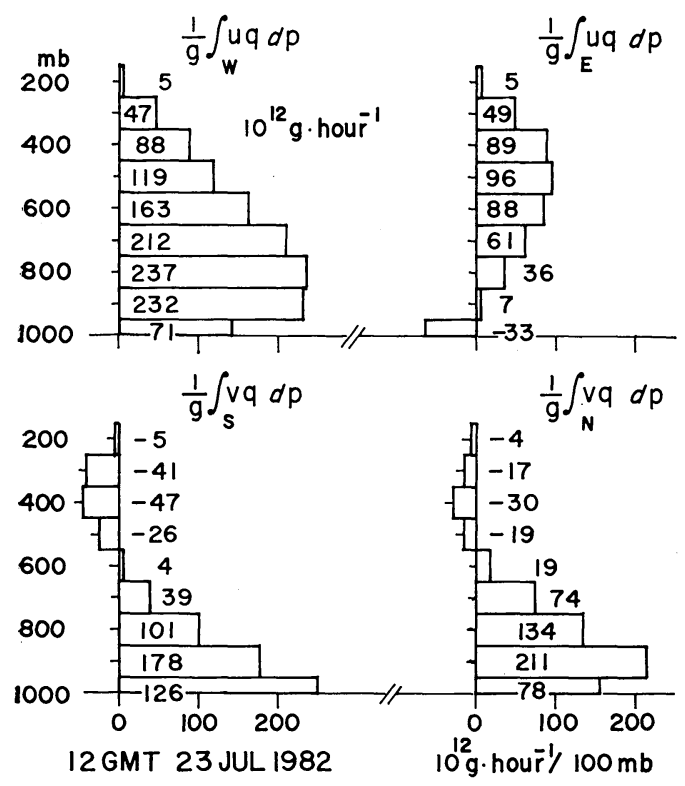

Fig. 21 Water vapor flux crossing the west, east, south and north boundary of $17 \times 17$ grid area including the heavy rainfall area at 12 GMT 23 July 1982 southwest of the heavy rainfall area and the southerly $\sim$ southeasterly wind to the northeast of the heavy rainfall area. We already infered that both the southwesterly and southeasterly winds were intensified through the diabatic heating in the heavy rainfall area, because the intensification of the southwesterly and the southeasterly winds is not proceeded in the dry experiment.

Fig. 22 shows the horizontal and three dimensional moisture convergence in each layer and vertical moisture flux at each level in the $17 \times 17$ grid area at 12 GMT 23 July. The horizontal moisture convergence is large in the lower troposphere $(650 \sim 1000 \mathrm{mb})$ and especially large in the lowermost layer (850 $1000 \mathrm{mb}$ ). About the half of the horizontal moisture convergence in the lower layer contributes to the three dimensional moisture

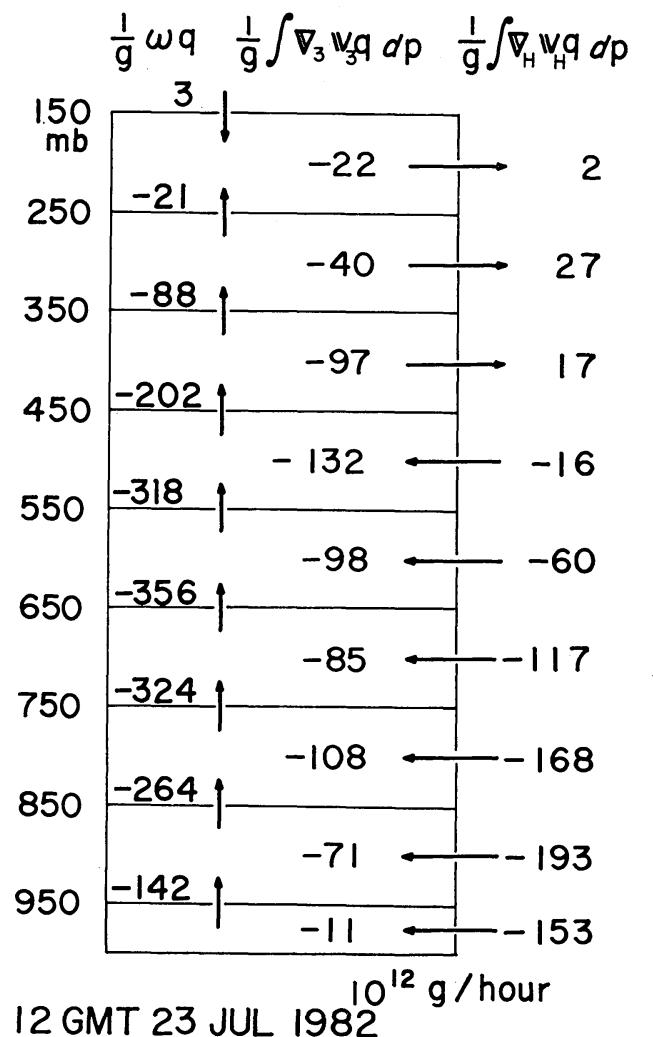

Fig. 22 Horizontal and three dimensional moisture flux convergence $\left(\nabla_{H} \boldsymbol{V}_{H} q\right.$ and $\left.\nabla_{3} \boldsymbol{V}_{3} q\right)$ in each layer and the vertical moisture flux $\omega q$ at each pressure level for the $17 \times 17$ grid area at 12 GMT 23 Jnly 1982 
convergence in the lower layer and the other half contributes to yield the large vertical moisture flux, which is maximized at $650 \mathrm{mb}$. In the middle upper troposphere (350 650 $\mathrm{mb})$, the horizontal moisture convergence is small and the large three dimensional moisture convergence is due to the large vertical moisture flux across the $650 \mathrm{mb}$ level. In short, large low-level horizontal moisture convergence feeds the three dimensional moisture convergence (i.e., the moisture sink) in both lower and middle troposphere (cf., Akiyama, 1975).

\subsection{Mesoscale features of divergence and vorticity field}

\section{Divergence and vorticity field in the lower} troposphere

We will examine the features of divergence $(D)$, vorticity $(\zeta)$ and kinetic energy $(K=1 / 2$ $\left.\left(u^{2}+v^{2}\right)\right)$ fields in and around the heavy rainfall area. Since these fields at 900, 800 and $700 \mathrm{mb}$ resemble each other, the maps of $D$, $\zeta$ and $K$ at $700 \mathrm{mb}$ at 12 GMT 23 July are presented in Fig. 23 as the example for the lower troposphere. Although these fields are complicated, we can find two kinds of pattern in $D, \zeta$ and $K$ fields. The first pattern is the "W-E pattern", i.e., the banded pattern extending from WNW to ESE. The second pattern is "N-S pattern", i.e., the banded pattern extending from NNW to SSE. These patterns are also found in the map of each term in the divergence and vorticity equations (see Fig. 24 and Fig. 25).

At $700 \mathrm{mb}$, there is a zone (W-E pattern) of large $K$ of $200 \mathrm{~m}^{2} / \mathrm{sec}^{2}$, which is relevant to the zone of low-level jet type strong WSW wind (see also $850 \mathrm{mb}$ wind field in Fig. 9). We also find a northward protruding branch (N-S pattern) of large $K$ area (see the isoline of $50 \mathrm{~m}^{2} / \mathrm{sec}^{2}$ ), which corresponds to the zone of strong S SSE wind in ahead of the meso$\alpha$-scale depression (the isallobalic low). The area of large cyclonic vorticity appears to the northside of the axis of WSW wind and to the west of the axis of S SSE wind. The large value of vorticity is attributed to the
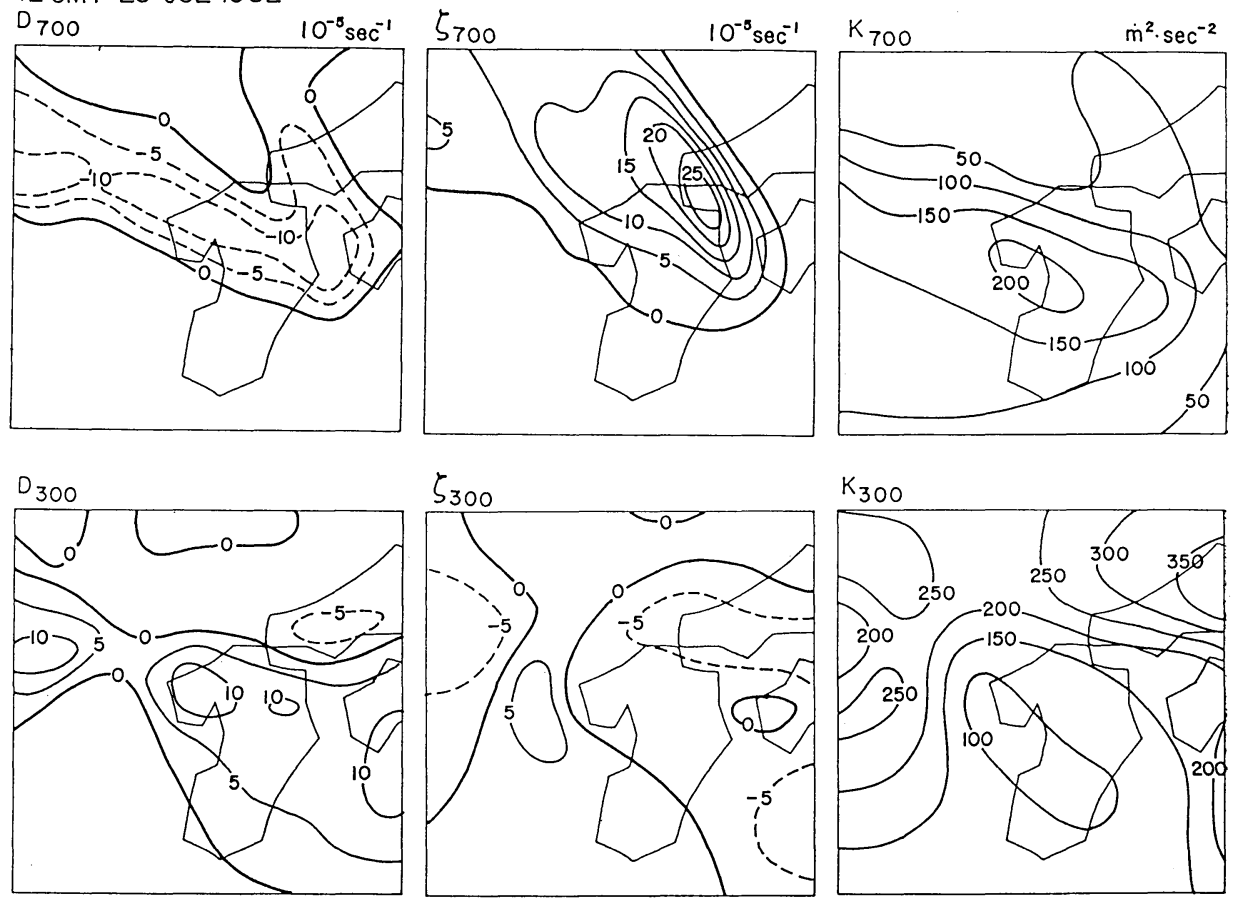

Fig. 23 Divergence (D), vorticity (ら) and kinetic energy

(K) field at $700 \mathrm{mb}$ and $300 \mathrm{mb}$ for 12 GMT 23 July 1982. 
I2 GMT 23 JUL $1982700 \mathrm{mb}$
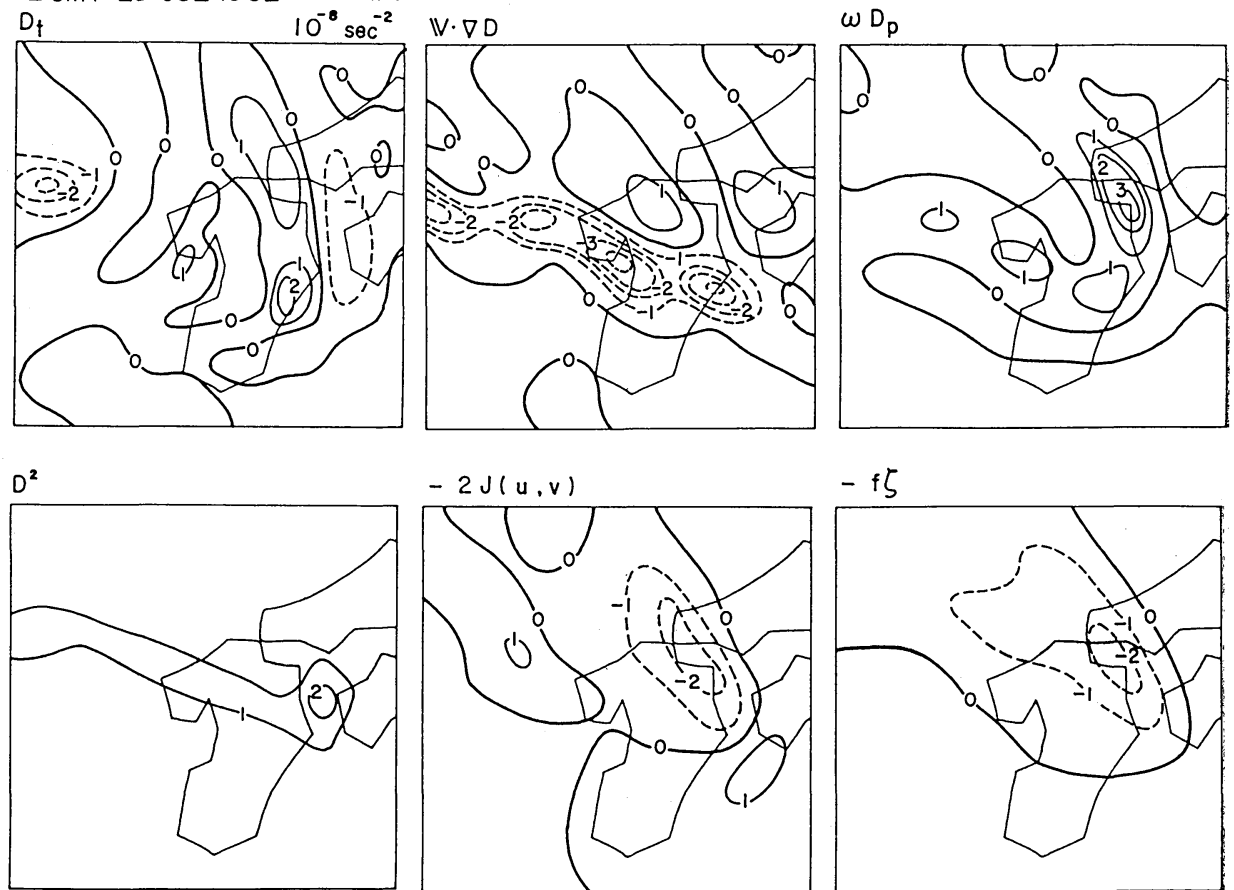

$-2 J(u, v)$

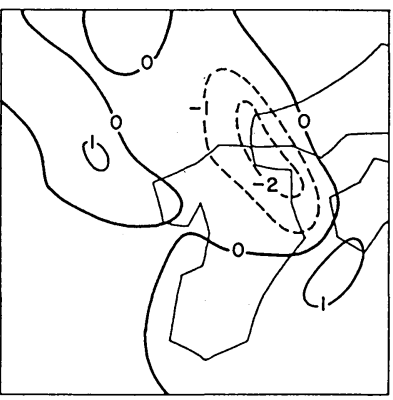

$-+5$
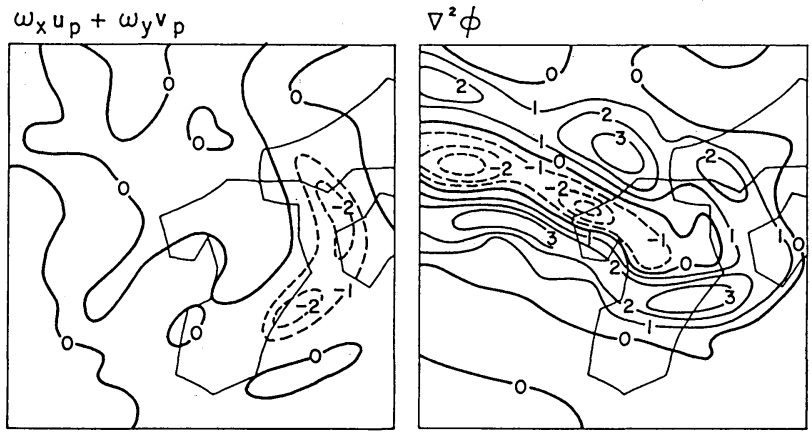

Fig. 24 The maps of terms in divergence equation at $700 \mathrm{mb}$ for 12 GMT 23 July 1982 .

strong curvature of the flow (i.e., the shear between SW and SE winds) around the depression.

The "W-E pattern" and "N-S pattern" are also evident in the divergence field at $700 \mathrm{mb}$. A zone of maximum convergence (W-E pattern) is found along the north side of the zone of the low-level jet type strong wind, and a secondary maximum zone of convergence (N-S pattern) is found in ahead of the vorticity maximum.

\section{Divergence and vorticity field in the upper troposphere}

The kinematic field at $300 \mathrm{mb}$ and $200 \mathrm{mb}$ resemble each other. We show $D, \zeta$ and $K$ field at $300 \mathrm{mb}$ as the examples for the upper layers. The $D, \zeta$ and $K$ fields in the upper troposphere are not complicated as comparing with those in the lower layers. There is an area of small $K\left(\sim 100 \mathrm{~m}^{2} / \mathrm{sec}^{2}\right)$ with anticyclonic vorticity and strong divergence over the heavy rainfall area. These features are commonly found over the intense convective* storms in both the actual atmosphere and in the numerical models (Fankhauser, 1969 ; Ninomiya, 1971 ; Anthes and Keyser, 1979 ; Maddox, 1980 ; Ninomiya and Tatsumi, 1981). This characteristic circulation system in the upper troposphere is induced by the intense convec- 

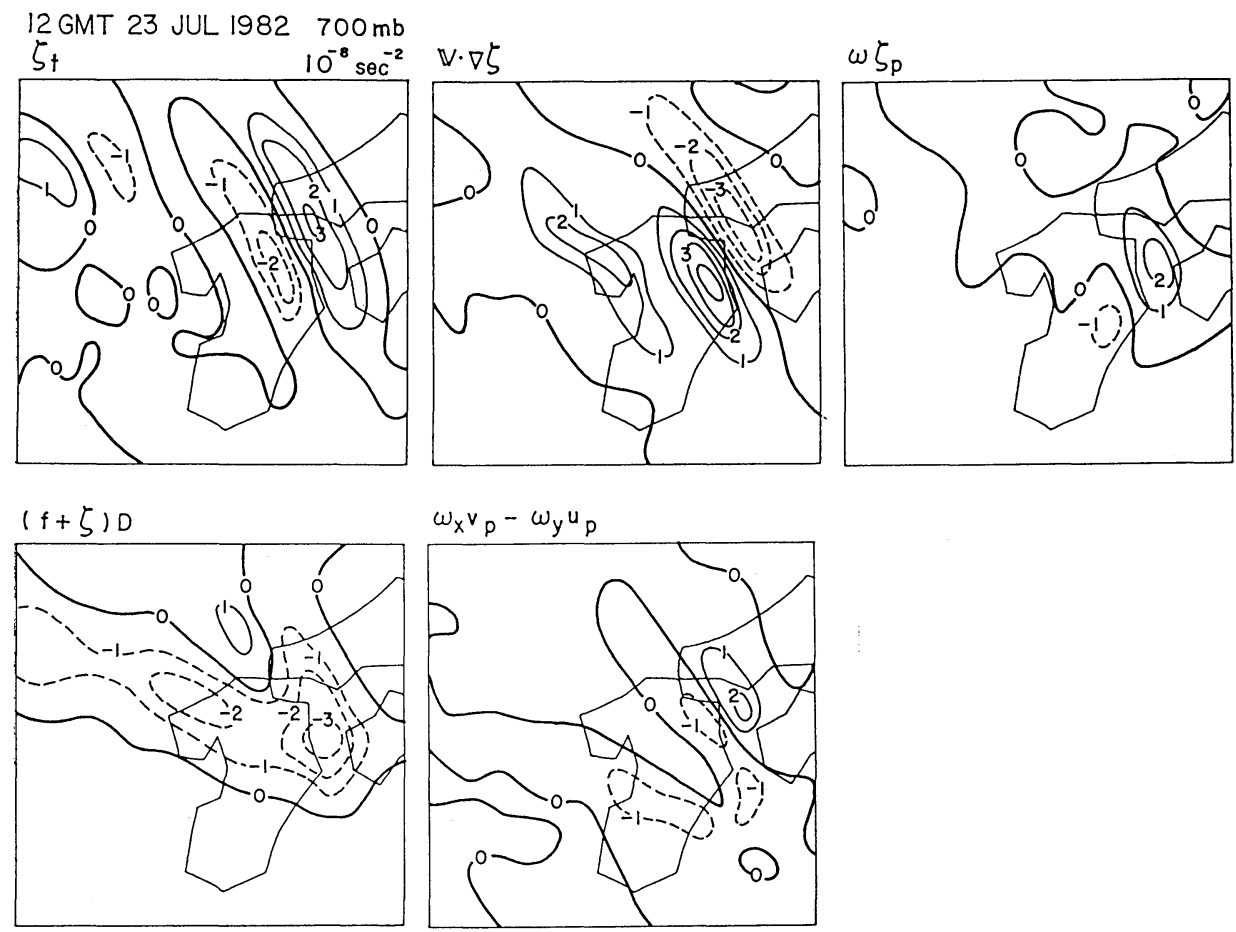

Fig. 25 The maps of terms in vorticity equation at $700 \mathrm{mb}$ for 12 GMT 23 July 1982.

tive motions in the heavy rainfall area.

\section{Balance in divergence and vorticity equation in the lower troposphere}

To understand the mechanism of the circulation system which is deeply related with the present heavy rainfall event, we examine the balance in the divergence and vorticity equations at $700 \mathrm{mb}$. They are

$$
\begin{aligned}
& \partial D / \partial t+\boldsymbol{V} \nabla D+\omega(\partial D / \partial p)+D^{2} \\
& \quad+(u(\partial f / \partial y)-v(\partial f / \partial x)) \\
& \quad+\left(\omega_{x} u_{p}+\omega_{y} v_{p}\right)-2 J(u, v)-f \zeta+\nabla^{2} \phi \\
& =0
\end{aligned}
$$

and

$$
\begin{gathered}
\partial \zeta / \partial t+\boldsymbol{V} \nabla \zeta+\omega(\partial \zeta / \partial p)+(f+\zeta) D \\
+\left(\omega_{x} v_{p}-\omega_{y} u_{p}\right)+\boldsymbol{V} \nabla f=0
\end{gathered}
$$

where $\phi$ is geopotential and $J(u, v)$ indicates $((\partial u / \partial x)(\partial v / \partial y)-(\partial u / \partial y)(\partial v / \partial x))$. The terms in eq. (1) and eq. (2) except $\partial D / \partial t$ and $\partial \zeta / \partial t$ are obtained from the model output for 12 GMT 23 July while $\partial D / \partial t$ and $\partial \zeta / \partial t$ are evaluated as the difference between 12 GMT and
11 GMT 23. Therefore we do not intend to discuss the exact balance in the equations but only study the basic mechanism of the mesoscale circulation system. The maps of these terms are presented in Fig. 24 and Fig. 25. The maps for $((u(\partial f / \partial y)-v(\partial f / \partial x))$ in eq. (1) and $\boldsymbol{V} \nabla f$ in eq. (2), which are one order smaller than the others, are omitted.

It is seen in Fig. 24 that W-E pattern predominates in $V \nabla D$ and $D^{2}$ field, and N-S pattern predominates in $D_{t}(=\partial D / \partial t),-2 J$, $-f \zeta$ and $\left(\omega_{x} u_{p}+\omega_{y} v_{p}\right)$ fields, while W-E pattern coexists with N-S pattern in $\omega D_{p}$ and $\nabla^{2} \phi$ fields. As for the W-E pattern, the major balance is held among $\nabla^{2} \phi, V \nabla D$ and $D^{2}$, while $D_{t}$ in $\mathrm{W}-\mathrm{E}$ pattern is small. This is relevant to the stationary convergence zone (W-E pattern) as seen in Fig. 23. It is inferred that the large value of $\nabla^{2} \phi$ (W-E pattern), which is resulted from the height fall in the heavy rainfall zone, contributes to form the convergence zone (W-E pattern), and that the balance between the advection term and the convergence generation term works to maintain the zonal convergence pattern, which 
is relevant to the heavy rainfall zone (cloud zone) extending from the East China Sea to Kyushu.

The balance in the divergence in $\mathrm{N}-\mathrm{S}$ pattern is more complicated. The magnitude of $\nabla^{2} \phi, \quad\left(\omega_{x} u_{p}+\omega_{y} v_{p}\right),-2 J,-f \zeta$ and $\omega D_{p}$ is comparable with each other. The $\nabla^{2} \phi$ in ahead of the meso- $\alpha$-scale depression (area of height fall) work to propagate the convergence area ( $\mathrm{N}-\mathrm{S}$ pattern) by producing the convergence, while $-2 J,-f \zeta,\left(\omega_{x} u_{p}+\omega_{y} v_{p}\right)$ and $\omega D_{p}$ cancels out each other. As a whole, the convergence area of $\mathrm{N}-\mathrm{S}$ pattern propagates slowly eastward.

Next we examine the maps for $\zeta$-equation in Fig. 25. Generally speaking, N-S pattern is predominant in the field of every terms, while $\mathrm{W}-\mathrm{E}$ pattern is seen in the western part of the maps for $(f+\zeta) D$ and $\left(\omega_{x} v_{p}-\omega_{y} u_{p}\right)$. The $\zeta_{t}(=\partial \zeta / \partial t)$ of $\mathrm{W}-\mathrm{E}$ pattern is small, as the W-E pattern of these terms cancels out each other. As for the N-S pattern, $(f+\zeta) D$ and $V \nabla \zeta$ are primary and, approximately speaking, explain the propagation and maintenance of the vorticity against the work of $\omega \zeta_{p}$ and $\left(\omega_{x} v_{p}-\omega_{y} u_{p}\right)$. In short, the strong convergence is thought to be essential to the propagation and maintenance of the vorticity of the meso- $\alpha$-scale circulation system of the present case.

\section{Prediction experiment of intense rainstorm of $22 \sim 23 \mathrm{July} 1983$}

On $22 \sim 23$ July 1983, extremely intense rainfalls occurred over the Japan Sea coastal area of the western part of Japan (Sanin District). The precipitation of $332 \mathrm{~mm}$ was recorded during 24-hour period between 15 GMT 22 and 15 GMT 23 July 1983 at Hamada City. Since this was also a typical case of intense rainfalls, we further carried out forecast experiment on this intense rainfall event by using the $13 \mathrm{~L} 42 \mathrm{~km}$-mesh primitive equation model.

First we briefly describe the observational features of this rainfall event. The surface analysis (map is not presented) indicates that a quasi-stationary front (Baiu front, see Matsumoto et al., 1971 and Akiyama, 1973 for the explanation on Baiu front) was extending from the southern part of China to the Pacific Ocean through the Japan Islands approximately along $35^{\circ} \mathrm{N}$ latitude circle. At 12 GMT 22 July 1983 , there was a weak meso- $\alpha$-scale frontal depression around $37^{\circ} \mathrm{N} / 132^{\circ} \mathrm{E}$. Fig. 26 is the map of $T_{B B}$ (cloud top IR black body temperature

TBB 12 GMT 22 JUL 1983

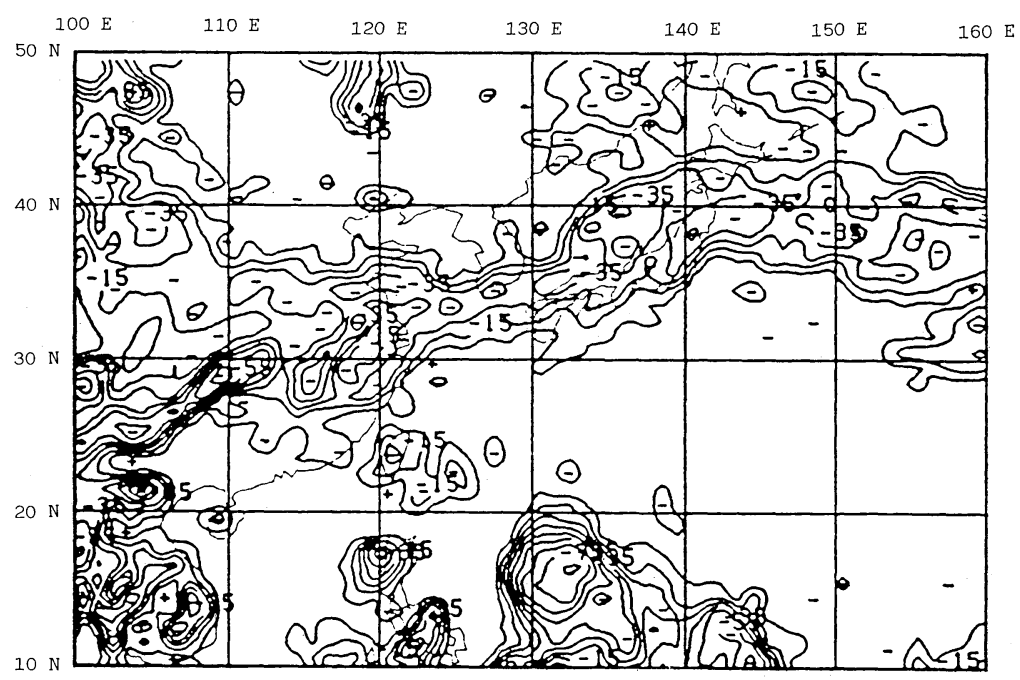

Fig. 26 Maps of $T_{B B}$ (cloud top IR black body temperature measured by Geostationary Meteorological Satellite) at 12 GMT 22 July 1983. The isolines are given at $10^{\circ} \mathrm{C}$ interval for $-45^{\circ} \mathrm{C},-35^{\circ} \mathrm{C},-25^{\circ} \mathrm{C},-15^{\circ} \mathrm{C}$ and $-5^{\circ} \mathrm{C}$. 

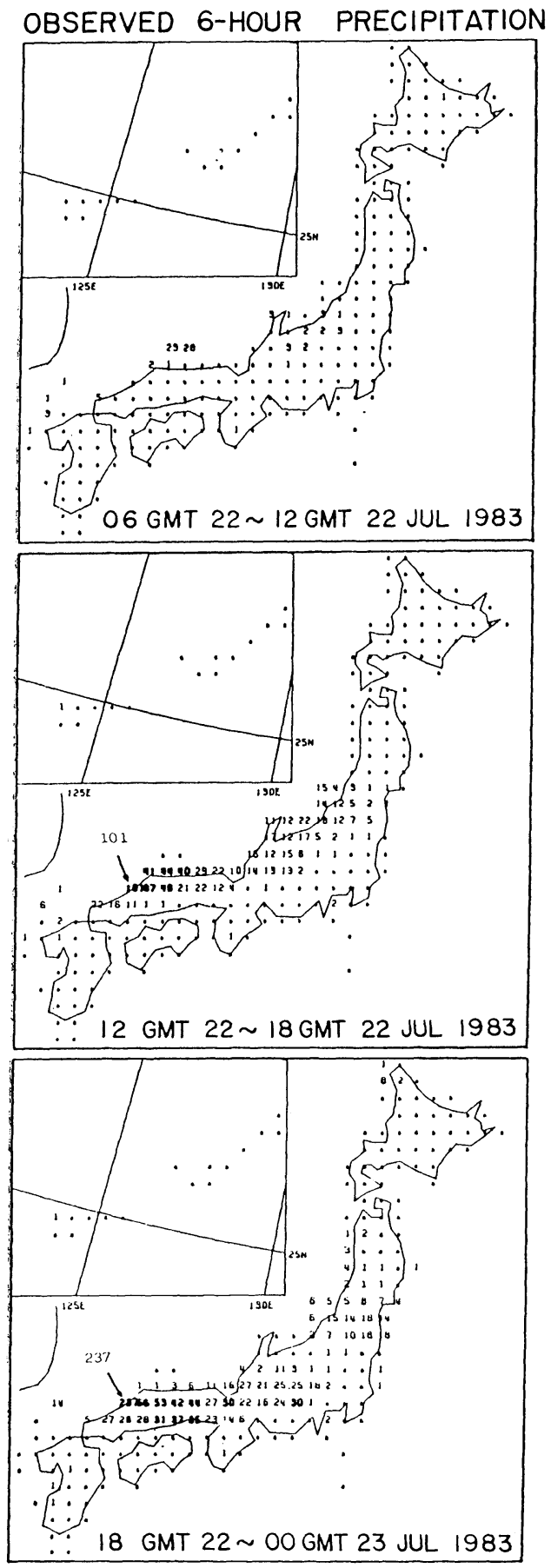

Fig. 27 The 6-hour precipitation maps for $06 \sim 12$ GMT 22, 12 18 GMT 22 and 18 GMT $22 \sim 00$ GMT 23 July 1983. The numeral in the maps indicates the areal averaged observed precipitation within each $63 \mathrm{~km}$ square area. measured by Geostationary Meteorological Satellite) at 12 GMT 22 July 1983. The cloud zone extending along $\sim 35^{\circ} \mathrm{N}$ latitude circle corresponds to the quasi-stationary front. Fig. 27 is the 6-hour precipitation maps for $06 \sim 12$ GMT 22, 12 18 GMT 22 and 18 GMT 22 00 GMT 23 July 1983. The numeral in the maps indicates the areal averaged precipitation within each $63 \mathrm{~km}$ square area. The 6-hour areal averaged precipitation was large in $12 \sim$ 18 GMT 22 and 18 GMT 22 00 GMT 23 July over Sanin District. The record of hourly precipitation at each station indicates, however, more complicated variation. At Hamada City, two peaks of precipitation were observed around 16 GMT 22 and 00 GMT 23 July 1983. The former occurred in the vicinity of the meso- $\alpha$-scale depression while the latter occurred after the passage of the depression.

The forecast experiment was made from the initial state at 00 GMT 22 July 1983 . The maps of predicted 6-hour precipitation for 06 $\sim 12$ GMT 22, 12 18 GMT 22 and 18 GMT 22 00 GMT 23 July 1983 are presented in Fig. 28. Although the 13L $42 \mathrm{~km}-$ mesh model was able to predict the precipitation concentrated within a narrow elongated zone, it was unable to predict the peak time of the intense precipitation accurately. The largest precipitation was predicted by the model in $06 \sim 12$ GMT in the vicinity of the meso- $\alpha$-scale depression. This peak period of the predicted precipitation preceded the occurrence of the actual intense precipitation about 6 hours. The model predicted that the area of the intense precipitation moved slowly eastward. The intensity of the precipitation in the model gradually weakened in 18 GMT $22 \sim 00$ GMT 23 July 1983, while the largest amount of precipitation took place in this period after the passage of the meso- $\alpha$-scale depression.

In short, the $13 \mathrm{~L} 42 \mathrm{~km}$-mesh model was able to predict the intense precipitation associated with the quasi-stationary front and the meso- $\alpha$-scale depression within a time difference of several hours, but unable to predict the intense precipitation which occurred after the passage of the depression.

We would infer that the intense precipitation in 18 GMT 22 00 GMT 23 was associated 
PREDICTED 6-HOUR PRECIPITATION
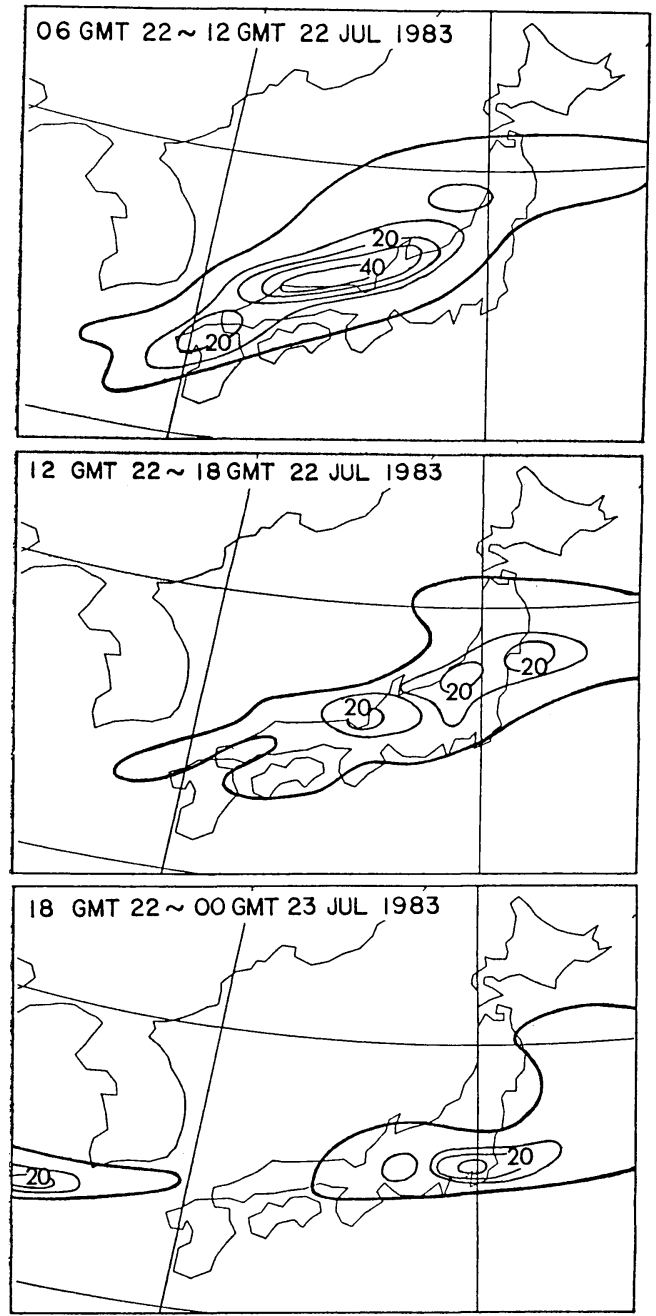

Fig. 28 Maps of 6-hour precipitation predicted by $13 \mathrm{~L} 42 \mathrm{~km}$-mesh model for $06 \sim 12 \mathrm{GMT}$ 22, $12 \sim 18 \mathrm{GMT} 22$ and $18 \mathrm{GMT} 22 \sim 00 \mathrm{GMT}$ 23 July 1983.

with some smaller disturbances and therefore was not predicted by the present model. The more detailed analysis of the present intense rainfall event and the detailed examination of the results of the forecast experiment are required. The remaining problems will be studied in the near future.

\section{Concluding remarks}

Forecast experiment was made using a 13level $42 \mathrm{~km}$-mesh primitive equation model for the extremely intense rainfall event which occurred over western Japan on 23 July 1982.
The concentration of rainfall, development of a meso- $\alpha$-scale depression and convergence zone were fairly accurately simulated in the model, although the amount of precipitation predicted by the model ( $\sim 70 \mathrm{~mm} / 6$ hour) was much smaller than the observed maximum rainfall rate $(\sim 300 \mathrm{~mm} / 6$ hour $)$.

The impact of the increased grid resolution of the model on the prediction of precipitation and the meso- $\alpha$-scale circulation system was examined by comparing the prediction by the present model with the results by a $63 \mathrm{~km}$ and $127 \mathrm{~km}$-mesh model. The increase of the grid resolution worked not only to concentrate the precipitation in the narrow area but also to increase the total (area integrated) precipitation. As compared with the $63 \mathrm{~km}$ - and $127 \mathrm{~km}$-mesh model, the $42 \mathrm{~km}$-mesh model consume more large amount of the moisture in the area surrounding the heavy rainfall area through the more intensified low-level convergence into the heavy rainfall area.

The thermodynamical and dynamical processes involved in the occurrence of the heavy rainfall, such as the moisture convergence, generation of convective instability in the heavy rainfall area and the convergence and vorticity balance in the meso- $\alpha$-scale circulation system were examined on the basis of the model output.

Although characteristic features of the meso- $\alpha$-scale depression and circulation system associated with the intense rainfall were fairly accurately simulated by the experiment, the predicted precipitation was much smaller than the observation and the meso- $\alpha$-scale circulation in the model was significantly weak as compared with the actual one in the experiment started from the initial state at 12 GMT 22. We expect that these failures of the model will be overcome by the more higher grid resolution, the improvement of the parameterization of the physical process and that of the initial analysis in the near future.

We also made a forecast experiment of an intense rainfall event over Sanin District of Japan in 22 23 July 1983 using the 13L 42 $\mathrm{km}$-mesh primitive equation model. For this case, the model was able to predict the intense precipitation associated with the stationary 
front and the meso- $\alpha$-scale depression within a time difference of several hours but unable to predict the intense precipitation occurred after the passage of the depression. The prediction of the intense precipitation which is associated with disturbance smaller than the meso- $\alpha$-scale is the remaining problem and should be solved in the future.

\section{Acknowledgements}

The present authors wish to express their sincere thanks to Professor Y. Ogura of the Illinois State University, who read the original manuscript and gave valuable suggestions and comments. Thanks are also due to Mr. R. Hasegawa of Forecast Division, Japan Meteorological Agency for valuable explanation and discussion on the observational features of the present rainstorm event.

\section{References}

Akiyama, T., 1973: The large-scale aspects of the characteristic features of the Baiu front. Pap. Met. Geophy., 24, 157-188.

- 1975 : Southerly transversal moisture flux into the extremely heavy rainfall zone in the Baiu season. J. Met. Soc. Japan, 53, 304-316.

- 1978 : Mesoscale pulsation of convective rain in medium-scale disturbances developed in Baiu season. J. Met. Soc. Japan, 56, 267-283.

- 1979 : Thermal stratification in Baiu frontal medium-scale disturbances with heavy rainfalls. J. Met. Soc. Japan, 57, 587-598.

Anthes, R.A. and D. Keyser, 1979: Tests of a fine mesh model over Europe and the United States. Mon. Wea. Rev., 107, 963-984.

Anthes, R.A., Y.-H. Kuo, S.G. Benjamine and Y.-F. Li, 1982: The evolution of the mesoscale environment of severe local storms. Mon. Wea. Rev., 110, 1187-1213.

Frankhausef, J.C., 1969: Convective processes resolved by a mesoscale rawinsonde network. $J$. App. Met., 8, 778-798.

Hovermale, J., 1975: Accuracy of prediction of heavy precipitation events in relation to grid resolution in numerical model. Briefing of performance of NMC hurricane model at NOAA/ NMC Hurricane Center at Miami 1975.

Kondo, J., 1975: Air-sea bulk transfer coefficients in diabatic conditions. Bound. Layer Meteor., $\mathbf{9}$, 91-112.
Maddox, R.A., 1980: An objective technique for separating macroscale and mesoscale features in meteorological data. Mon. Wea. Rev., 108, 11081121.

Matsumoto, S., K. Ninomiya and S. Yoshizumi, 1971 : Characteristic features of Baiu front associated with heavy rainfall. J. Met. Soc. Japan, 49, 267-281.

Miyakoda, K. and A. Rosati, 1977 : One-way nested grid model. Mon. Wea. Rev., 105, 1092-1107.

Ninomiya, K., 1971: Dynamical analysis of outflow from tornade-producing thunder-storms as revealed by ATS-III pictures. J. App. Met., 10, 275294.

Ninomiya, K. and T. Akiyama, 1972: Medium-scale echo clusters in the Baiu front as revealed by multi-radar composite echo map. Part 1. J. Met. Soc. Japan, 50, 558-569.

- and — 1974: Band structure of mesoscale echo cluster associated with low-level jet stream. J. Met. Soc. Japan, 52, 300-313.

Ninomiya, K., M. Ikawa and T. Akiyama, 1981 : Long-lived medium-scale cumulonimbus cluster in Asian subtropical humid region. J. Met. Soc. Japan, 59, 564-577.

Ninomiya, K. and Y. Tatsumi, 1980: Front with heavy rainfalls in the Asian subtropical humid region in a 6 -level $77 \mathrm{~km}$-mesh primitive equation model. J. Met. Soc. Japan, 58, 172-186.

- and — 1981 : Forecast experiment of long-lived subtropical cumulonimbus cluster with 6 -level $77 \mathrm{~km}$-mesh primitive model. J. Met. Soc. Japan, 59, 709-722.

Ninomiya, K. and K. Yamasaki, 1979: Heavy rainfalls associated with frontal depression in Asian subtropical humid region (II). J. Met. Soc. Japan, 57, 399-413.

Ross, B. and I. Orlanski, 1982: The evolution of an observed cold front. Part I. J. Atm. Sci., 39, 296-327.

Staff members of Electronic Computation Center, Japan Meteorological Agency, 1983: Outline of Operational Numerical Weather Prediction at Japan Meteorological Agency, 48-62.

Takigawa, U., 1983: Eight-level northern hemispheric model. Electronic Computation Center Report. No. 29. Japan Met. Agency, 31-44 (in Japanese)

Tatsumi, Y., 1983: An economical explicit time integration scheme for primitive model. J. Met. Soc. Japan, 61, 269-288.

Yoshizumi, S., 1977: On the structure of intermediate-scale disturbances on the Baiu front. $J$. Met. Soc. Japan, 55, 107-120. 


\title{
微格子プリミティブ・モデルによる長崎豪雨の予報実験
}

\author{
二 宮 洸 三 \\ 仙台管区気象台
}

\section{古賀晴 成・山岸米二郎・翼 保夫}

気象庁電計室

1982年 7 月 23 日九州西北部（長崎市近傍）で豪雨（ 400 mm/ 1 日）が発生した。この豪雨の予報実験を 13 層 $42 \mathrm{~km}$ 格子プリミティブ・モデルによって行なった。

九州北西部に集中した降水, その近傍における小低気圧と循環系の形成は24時間予報でかなり正確にシミュ レートされた。しかし実況に比較すると予報雨量（７0 mm/6時間）も低気圧の深まりも不充分である。特に 22 日12時 (GMT) を初期値とする予報実験では spin up に時間がかかり, はじめの12時間の降雨, 低気圧発達 が不充分であった。これらの問題は残るが，微格子モデルによる豪雨予報の可能性が示されたものと考方る。 非断熱過程の効果を確かめるため dry model による実験を行ならと, 小低気圧の発達はなく上昇流も非常 に弱い。降雨にともなら非断熱効果がさらに降雨を強めるといら作用が推論される。

モデルの分解能增加の効果を見るため, 11層 $63 \mathrm{~km}$ 格子, 10 層 $127 \mathrm{~km}$ 格子および 8 層 $381 \mathrm{~km}$ 格子モデル の予報と比較した。分解能増加によって降雨の集中性が強まるだけでなく, 総（面積積算）雨量も増加する。 分解能を増すと豪雨域周辺から豪雨域へ流入する水蒸気流束が増大するからである。

実験データにもとづき, 豪雨域の水蒸気収支, 対流不安定の生成, 発散方程式および渦度方程式のバランス を解析した。

さらに1983年 7 月22 23日の山陰豪雨の予報実験を行った。東西にのびる豪雨域は予報されたが，予報され た豪雨のピーク時と観測されたピークとの間には数時間の差があり, 前線上の弱い小低気圧近傍の降雨は実際 よりはやく予報され，一方小低気圧通過後の降雨は予報されなかった。小低気圧にともなわない降水が予報さ れなかった理由は現在不明である。 